\title{
Engaging men for effective family planning through couple communication: An assessment of two MCSP couple communication approaches in Togo
}

Natacha Stevanovic-Fenn

Bethany Arnold

Sanyukta Mathur

Population Council

Catherine Tier

Anne Pfitzer

See next page for additional authors

Follow this and additional works at: https://knowledgecommons.popcouncil.org/departments_sbsr-rh

Part of the Health Communication Commons, and the Public Health Commons

How does access to this work benefit you? Let us know!

\section{Recommended Citation}

Stevanovic-Fenn, Natacha, Bethany Arnold, Sanyukta Mathur, Catherine Tier, Anne Pfitzer, and Rebecka Lundgren. 2019. "Engaging men for effective family planning through couple communication: An assessment of two MCSP couple communication approaches in Togo," Study Report. Washington, DC: Population Council, Breakthrough RESEARCH. 


\section{Authors}

Natacha Stevanovic-Fenn, Bethany Arnold, Sanyukta Mathur, Catherine Tier, Anne Pfitzer, and Rebecka Lundgren 


\section{STUDY REPORT}

\section{Engaging Men for Effective Family Planning through Couple}

Communication: An Assessment of two MCSP Couple Communication Approaches in Togo

NATACHA STEVANOVIC-FENN BETHANY ARNOLD SANYUKTA MATHUR CATHERINE TIER ANNE PFITZER REBECKA LUNDGREN 
Reproductive Health at Georgetown University, Population Reference Bureau, and Tulane University.

\section{Acknowledgements}

This research report was prepared by Natacha Stevanovic-Fenn, Rebecka Lundgren and Catherine Tier of the Institute for Reproductive Health (IRH), Bethany Arnold and Anne Pfitzer of Jhpiego MCSP, and Sanyukta Mathur of Population Council under the Breakthrough RESEARCH Project. Our special thanks go to Lea Satta of IRH for her thoughtful comments and contributions to the analysis. We would also like to express our sincere gratitude to Idrissou Daoudou of International Planned Parenthood Federation (IPPF) as well as to Thomas Deglo and John Abgodjavou of Jhpiego / MCSP - Togo for their continued support and invaluable contributions towards the completion of this study. Thanks also to Laura Reichenbach at Population Council and Lindsay Swisher at USAID for their helpful feedback on the report. Our gratitude to Joan Kraft at USAID for her support and insightful inputs throughout the study.

(C) 2019 Institute for Reproductive Health, Georgetown University

\section{Recommended Citation:}

Stevanovic-Fenn, N., Arnold, B., Mathur, S., Tier, C., Pfitzer, A. and Lundgren, R. 2019. "Engaging Men for Effective Family Planning through Couple Communication: An Assessment of two MCSP Couple Communication Approaches in Togo." Study Report. Washington, D.C.: Population Council, Breakthrough RESEARCH.

Contact

3300 Whitehaven Street, NW Suite 1200

Washington, DC 20007

irhinfo@georgetown.edu

https://breakthroughactionandresearch.org 


\section{Table of Contents}

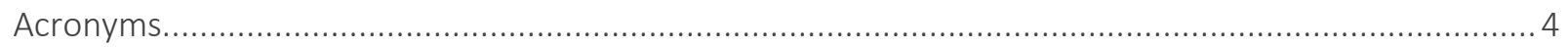

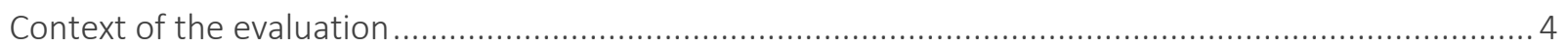

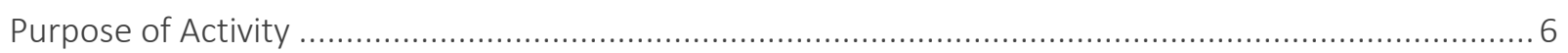

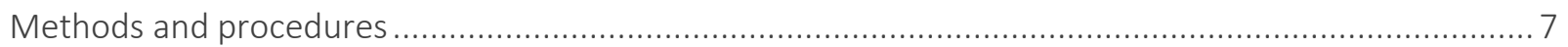

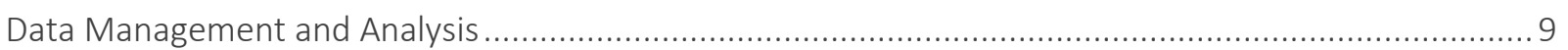

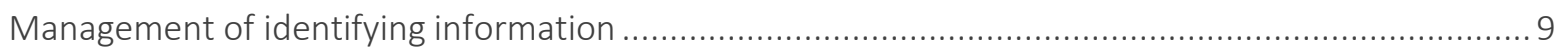

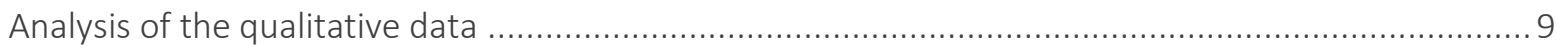

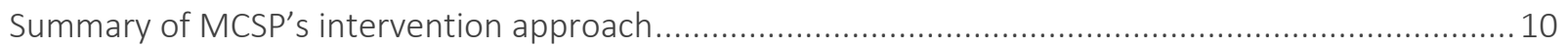

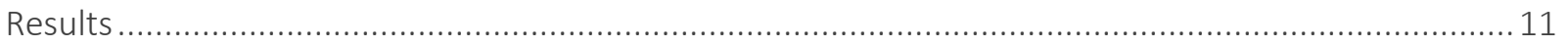

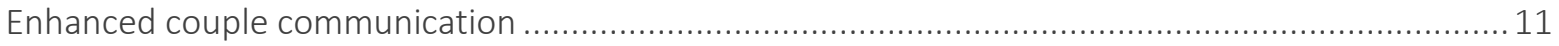

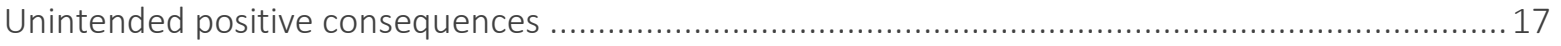

Gender differences around couple communication approaches' preferences and perceived needs 19

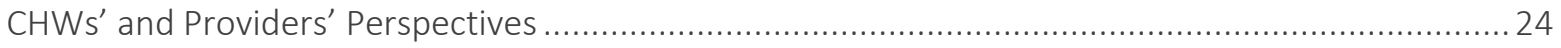

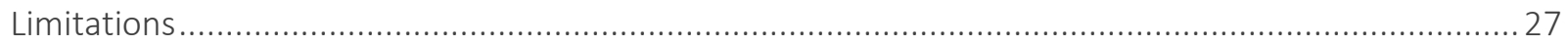

Key Takeaways and Learnings from MCSP's Couple Communication Intervention............................28

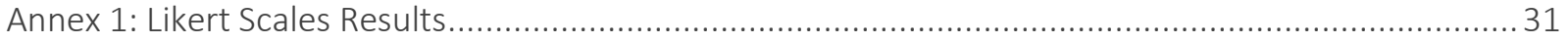

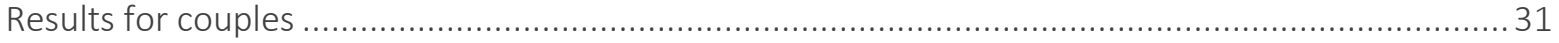

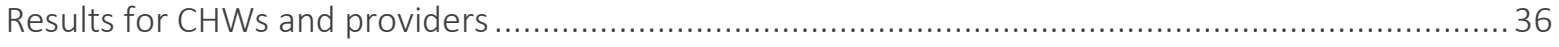

Annex 2: Resources and commodities essential for supporting family-planning interventions in the

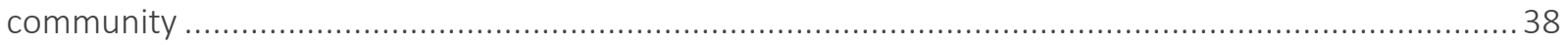

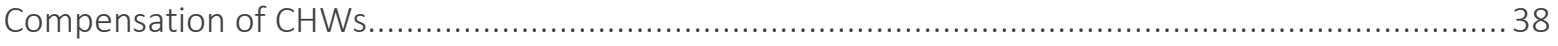

Availability of contraceptive/FP commodities and services at the facility and community level,

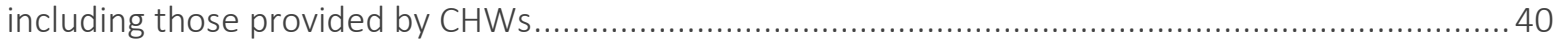

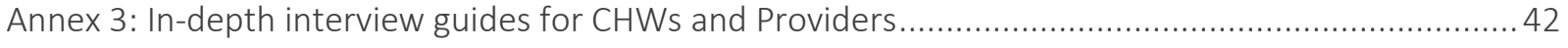

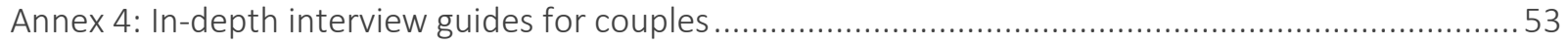




\section{Acronyms}

\begin{tabular}{|c|c|}
\hline ATBF & Association Togolaise pour le Bien-Être Familiale \\
\hline BTL & Bilateral Tubal Ligation \\
\hline CHWs & Community Health Workers \\
\hline DSMI/FP & $\begin{array}{l}\text { Division de la Santé Maternelle et Infantile et de la } \\
\text { Planification Familiale }\end{array}$ \\
\hline FGD & Focus group discussion \\
\hline FP & Family planning \\
\hline IDI & In-depth interview \\
\hline IRH & Institute for Reproductive Health, Georgetown University \\
\hline MCSP & Maternal Child and Survival Project \\
\hline $\mathrm{MOH}$ & Ministry of Health \\
\hline NGO & Non-governmental organization \\
\hline SBC & Social and Behavior Change \\
\hline $\mathrm{SRH}$ & Sexual and reproductive health \\
\hline USAID & United States Agency for International Development \\
\hline
\end{tabular}

Context of the evaluation 
In the past decade, the Government of Togo has made great strides to improve access to family planning (FP) services by implementing a range of activities, including provision of free family planning services with the support of NGOs and various local associations. ${ }^{1}$ As part of this progress, the government has committed to meet existing needs and remove the barriers that prevent women and men from using FP services. Such initiatives have thus far shown improvements in increasing the modern contraceptive prevalence rate by almost $6 \%$ from 2013, reaching 23.3\% in 2017. ${ }^{2}$ Research shows a positive association between partner communication and contraceptive use, and thus suggests the benefits of engaging both female and male partners in sexual and reproductive health (SRH) and FP services and decisions. ${ }^{345}$ Couple counseling programs have had particularly promising results to this end, improving partners' overall communication and

Box I: Why engage both female and male partners in Sexual and Reproductive Health and FP services?

- Both women and men want male partners to be more involved in FP.

- Men exert powerful influence on their partners' pregnancy and FP intentions.

- Men themselves are active agents - in their role as both users and partners - of FP use.

- Couple communication and gender equitable decision-making are key to improved contraceptive use. in some cases, FP use (although the evidence for use of contraception is mixed). ${ }^{6}$

In Togo, the USAID-funded Maternal and Child Survival Project (MCSP) is strengthening and expanding the availability of FP services to women, men, and couples through FP counseling and provision of FP methods. In the Kloto District of Togo, MCSP has designed several male engagement and couple communication interventions with potential for scale. 


\title{
Purpose of Activity
}

\begin{abstract}
Togo
Ghana Benin

Kloto

Wheto

townships (cantons) in Kpalimé.
\end{abstract}

In-home couple counseling (Canton of Kpimé, 15 villages) approach. CHWs delivered sessions at home either for the couple or individually, if an individual preferred individual counseling. CHWs used communication and counseling materials promoting male engagement, developed by MCSP, to structure the counseling conversations. Topics included discussions on effective communication techniques for couples, couples accessing FP services together, male partners accompanying their female partners to health facilities for services (ANC, PNC, FP, childhood immunization visits, etc.), benefits of men actively supporting their female partners and families in daily activities, and no scalpel vasectomy services.

Group discussions (Canton of Kpadapé, 4 villages) approach. ${ }^{8}$ CHWs delivered four sessions, featuring a series of five digital videos covering similar themes as the home-based counseling (e.g. Male engagement, FP topics, etc.) with guided group reflection (causeries éducatives). The discussions occurred in both mixed and same-sex groups. In some instances, the wife participated without the husband, or vice versa, if one was unable to attend. The CHW kept a record of who had not been able to participate and later paid a separate home visit to ensure that the couple received the information that was discussed during the group-based couple discussion.

The objectives of this case study were to explore and describe how the two couple communication approaches might influence pathways and decision-making associated with SRH and FP behaviors for participating couples, and to describe the experiences and behaviors of service providers and CHWs in delivering the couple communication activities. The case study also sought to explore potential behavior changes among couples, as well as providers and CHWs. 


\section{Methods and procedures}

The research consisted of two phases of data collection across two sites - Kpimé and Kpadapé-to capture the perspectives and experiences of providers, CHWs and couples. Phase 1 occurred in November 2018, while Phase 2 data collection was conducted in May/June 2019, consisting of repeated interviews with the same study participants. Up to thirty-two in-depth interviews were conducted per round with 12 couples, $6 \mathrm{CHWs}$, 2 service providers ${ }^{9}$ and 1 MCSP representative. One couple was replaced for the second phase of data collection due to lack of follow-up from Phase 1. Additional data collection included a group discussion with technical staff at the Ministry of Health and partners involved in the MCSP program and two key informant interviews with technical staff from DSMI/PF and MCSP. Data on study participants are presented in Table 1.

Table 1: Study participants

\begin{tabular}{|c|c|c|c|c|c|}
\hline \multirow[t]{2}{*}{ IDI participants } & \multicolumn{2}{|c|}{ Kpadapé } & \multicolumn{2}{|c|}{ Kpimé } & Total \\
\hline & Women & Men & Women & & \\
\hline Matched couples & 6 & 6 & 6 & 6 & 24 \\
\hline CHWs & 1 & 2 & 1 & 2 & 6 \\
\hline Providers & 1 & 0 & 0 & 1 & 2 \\
\hline Total participants & & & & & 32 \\
\hline
\end{tabular}

In addition, one group discussion with key actors involved in the MCSP program and two key informant interviews with MCSP and the director of the Kpalimé hospital were conducted as a way of engaging community members involved in the intervention in a culturally appropriate manner. This group discussion also provided an opportunity to get more information about the context within which the intervention was implemented.

In addition, we piloted measures for self-efficacy scales around couple communication (1) to capture couples' perceptions of behavior change in relation to FP desires and contraception use and (2) to assess CHW's ability to provide FP counseling to couples. ${ }^{10}$ The self-efficacy questions were developed on the basis 
of validated self-efficacy measures applied in reproductive empowerment and decision-making as well as in patient-service provider communication. ${ }^{11}$

- Couples completed two scales to estimate their perceived self-efficacy to discuss FP and contraception. Questions included comfort in discussing number of children, whether or not the respondent would have the "last word" in a discussion on contraception, and if the respondent thought they could influence the decision to use contraception. Couples responded to the scale around the beginning of the implementation of the counseling activities and seven months later.

- In month One and month Seven, six CHWs and two providers answered questions on their self-efficacy in implementing family planning counseling. Respondents were asked to rate their confidence in key elements of counseling, such as maintaining confidentiality or resolving conflicts.

Prior to data collection, a study research team consisting of a lead Togolese researcher and two Togolese (female and male) research assistants were trained by the lead researcher from IRH on qualitative research methods, basic gender analysis, as well as on the objectives of the assessment and related research tools. Trained research assistants used a semi-structured questionnaire to elicit in-depth information on couples', providers' and CHWs' communication experiences before, during and after attending counseling sessions and group discussions. In-depth interviews with couples also gave participants an opportunity to share, in their own words, their thoughts, feelings and experiences with the two couple communication approaches as a result of attending couple counseling and group discussions. Males and females were interviewed separately, and specific safeguards were taken to guarantee the voluntary and confidential participation of the intervention participants so that one respondent did not find out what the other reported (see details on safeguards in the section on Data Management and Analysis).

The study was approved by the Georgetown University Institutional Review Board (Washington, DC) and the Comité de Bioéthique pour la Recherche en Santé (Togo). All participants consented verbally to take part in the study through an informed consent process reviewed and approved by the Georgetown University Institutional Review Board and the Togolese Bioethic Committee. 


\section{Data Management and Analysis}

\section{Management of identifying information}

The study research team de-identified all data that were collected to protect the identities of individual participants. Codes were used in lieu of participants' names, so that names cannot be linked back to their interviews.

\section{Analysis of the qualitative data}

All interviews were audio recorded and transcribed verbatim from Ewe to French. They were then analyzed in French, using thematic analysis of textual data. Data analysis was done through repeated reading and note taking of the transcribed data from the interviews. The lead researcher generated thematic coding after reviewing and defining themes which served as the basis for interpretive analysis for these data. The lead researcher assessed the codes with the data collection team and together, the codes were finalized for reliability. In addition, the data collection team completed a final review of the analysis before it was integrated into this report. The results are structured under the following themes that emerged from the interviews:

- Couple dynamics, communication and decision-making around SRH and FP before, during and after the couple counseling and group discussions sessions;

- Experiences in the home counseling sessions versus group discussions, including perceived benefits and challenges;

- Method choice and use or non-use of health services for FP and other SRH services;

- CHW and provider perspectives on counseling and group discussions sessions and couple communication;

- Recommendations for counseling session improvements; and

- Self-efficacy questionnaire to detect change in improved communication and decision-making related to FP desires and method use with their partner. 


\section{Summary of MCSP's intervention approach}

In August 2016, MCSP conducted a rapid formative assessment in collaboration with the Association Togolaise pour le Bien-Etre Familiale (ATBEF) and the $\mathrm{DSMI} / \mathrm{PF}$ to better understand the interest, motivators, and barriers to promote male engagement in FP. ${ }^{12}$ Based on this assessment, findings pointed to the need to incorporate a gender sensitive and transformative approach into the activities in order to address unequal power relations and gender roles within the home. As a result, MCSP included a gender component (e.g. promoting male engagement) early on in the intervention, training health providers and CHWs on themes related to gender transformative programming (e.g. addressing gender roles and power within the home) and

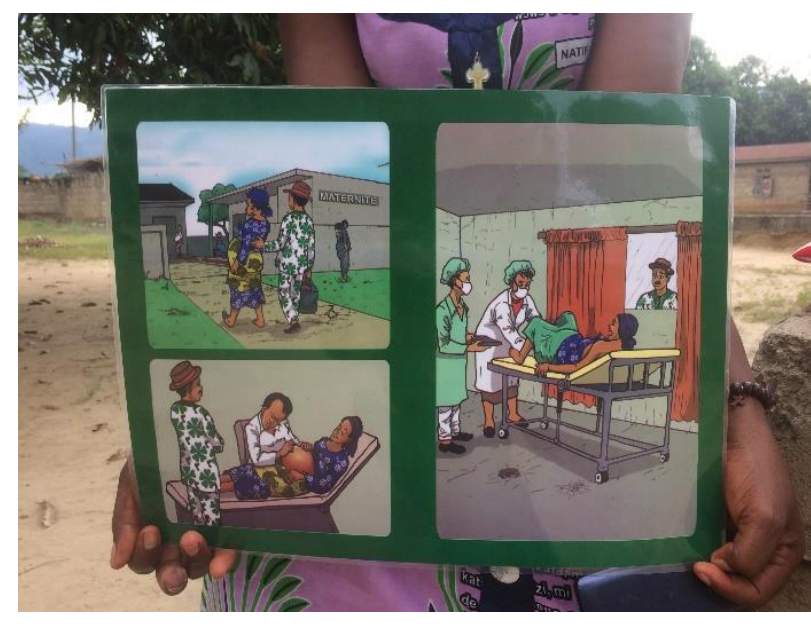

A Community Health Worker holding a flipchart developed by MCSP, showing a husband accompanying his wife to the hospital. Photo Credit: Natacha Stevanovic-Fenn, Kpimé positive masculinity, and as part of the counseling sessions to respond to couples' desires for promoting gender equity at home as well as in FP use. In Togo's Kloto district, MCSP implemented an FP intervention aimed at promoting men's engagement in the health of their families, including FP use.

The MCSP FP intervention was implemented in three zones around the Kloto Health District and included the following activities: 1) home-based, individual couple counseling using counseling cards; 2) group discussions which included either group-based discussions using digital videos as well as causeries éducative (guided discussion and reflection); 3) integration of principles and benefits of couple communication and use of positive deviants into Husbands Schools (Ecole des Maris)-using some champion engaged men in the community to mentor and strengthen other men in the community to promote couple communication and positive masculinity; and; 4) expansion of no scalpel vasectomy services in the district hospital of Kpalimé serving all three zones.

CHWs, the primary counselors for the first two activities, were trained on four modules: family planning, couple communication, gender norms and intimate partner violence (IPV). Couples who were visited by $\mathrm{CHWs}$ or participated in group discussions and were interested in FP and other services were linked to local service providers (from the three zones, the district hospital, and the prefectural hospital), who were also trained on the same four topics related to couple communication and engaging men. Together, MCSP trained a total of 13 men and eight women CHWs; six men and eight women providers; and 11 men from the Ecole des Maris for couple counseling. Trainings were rolled out in October and November 2018, with subsequent activities continuing through June 2019. 


\section{Results}

The section presents the data collection results from Phase 1 and Phase 2, organized by four key thematic areas that emerged during analysis: i) enhanced couple communication; ii) unintended positive consequences; iii) gender differences around couple communication approaches; and iv) CHWs' and providers' perspectives and experiences delivering couple counseling and group discussions. ${ }^{13}$ Overall, no major changes in couple and CHW responses were found between Phase 1 and Phase 2, except for a few differences which we have noted in the findings sections below. Thus, the results of both phases of data collection are presented together.

\section{Enhanced couple communication}

Overall, there was a general consensus among all interviewed women and men (matched couples) that the two couple communication approaches-home-based couple counseling and group discussions-yielded positive effects, such as improving couple communication and harmony within the home, even after attending only one session. Couples said that counseling facilitated open communication, not just on family planning (FP), but on each other's aspirations and expectations. Specifically, home-based counseling also helped couples learn more productive ways of settling differences by identifying individual problems and working together, with the help of the CHWs, to find solutions. One respondent noted that the counseling made him feel more comfortable expressing views that were different from his wife, which CHWs helped the couple work through.

"The CHW came twice to our house and she explained my husband should help with the children and house chores. Since then, he helps me and we laugh together and talk more about what we need to make our relationship better." - Female partner, Kpadapé

"The session has advantages for the couple. When I talk to my friends they understand, because arguing always in your relationship affects the children's education and studies. Harmony in the relationship promotes the children's development." - Male partner, Kpadapé

"It's the fact that we're told about unity, solidarity within the couple that I liked a lot. There is peace and understanding in my relationship thanks to the counseling. Before, we would argue in front of the children, but with the counseling sessions we no longer do that." - Male partner, Kpimé

"Before, we don't know how to talk to each other, but since we started the sessions, it started getting better little by little." - Female partner, Kpimé 


\section{- Men's awareness, knowledge, and support for their partner's SRH}

Couples noted that couple counseling helped them gain knowledge and insight into contraceptive use and the benefits of men's involvement in family planning decision-making. Several men reported that knowing about the variety of contraceptive options available makes it easier to engage in conversations on FP intentions and arrive at a joint decision on which method to use. Male respondents also mentioned that counseling helped them realize that spacing pregnancies is directly related to the overall health and financial security of their family. Interviews with women revealed similar results. They observed that after attending couple counseling and group discussions, men were more likely to engage in discussions related to SRH and other health-related matters, including those of their children. Several men reported that before participating in couple communication activities, they always thought of SRH as a woman's business, but they were now more aware of the need to be engaged, particularly in achieving family cohesion. Two men also mentioned that they had learned about FP methods that men can also use. While for some, couple communication activities represent a path towards couple harmony, others viewed their involvement as a way to gain more information on FP and the side effects of modern contraception.

"During the sessions, I learned about contraceptive methods, how to do family planning."- Male partner, Kpadapé

"The theme that most interested me was about how to take care of children and how to space births. What I learned was that a pregnant woman cannot wait to be pregnant to go to a health center and take care of herself. She can't wait to faint to use a health center. What I ignored before was that you don't have to wait to be sick to go to the hospital." - Female partner, Kpimé.

"I understood the need to space pregnancies and the husband's duty to help his wife with household tasks. Because in the past I thought these tasks only belonged to women." - Male partner, Kpimé.

"The message I kept is the importance of spacing pregnancies and husbands accompanying wives to the health center. I really liked these themes, especially because spouses have a duty to support each other mutually in every situation." - Female partner, Kpimé.

\section{- Increased men's awareness of workload sharing benefits}

Another crucial aspect of improved couple communication that both women and men noted is that homebased counseling and group discussions provide the opportunity for couples to rethink inequitable gender roles within the household. Interviews with both women and men indicate that discussion of gender equitable household roles and the need for men to participate in household tasks were the most appreciated element of the counseling (for men in particular). Several men admitted that they were not aware that shared responsibility could strengthen a couple's relationship but noted that after they became 
more involved in household roles, their relationships with their wives improved because their wives felt more appreciated. These views coincide with women's accounts, which described men being more involved in the home, such as fetching water, cooking, or cleaning the house. Both men and women also noted how men became more involved with their children as a result of the intervention, including increased childcare, more discussion of school-related matters, and not arguing as much in front of the children.

"The CHW teaches us a lot of things. For example, I learned that I have to help my wife in domestic chores. I didn't use to do it because our traditions didn't allow a man to help your wife in house chores. You know, a man who does it, then he will be seen like his wife dominates him and then people in the community, they will look down upon you. But now, I really understand the benefits of helping my wife. It's good for the overall harmony of our household." - Male partner, Kpimé

"When the CHW told us about how it's important to help your wife in housework, my husband started telling me that he also has work to do and when he comes home, he's too tired. But little by little, you know, he started to help me with children while I am cooking. And then, little by little he sees how happy it makes me." - Female partner, Kpadapé

"The home counseling sessions helped us practice helping each other. For example, I no longer let my wife carry the firewood and our child on her back when we come back from the field." - Male partner, Kpadapé

"Our behaviors towards our children have improved. We speak to them with more love and understanding. My husband also takes more of an interest in the children's educations." - Female partner, Kpimé

Although men support the idea of sharing the domestic and care workload with their female partner, several men did note that, at times, they see the redistribution of work as an unfair burden added to their already heavy daily workload. In fact, a few men voiced concerns that women would get used to their husbands helping, leaving much of the burden on them to not only contribute paid work but also unpaid work in the household.

"We learn a lot about the need to help our wives in the home. I am not against it but I have to manage my work during the day and then when I come home from work, I have to keep working and I get tired, you know. My wife likes it when I help her but then she gets used to it and I feel like I am working a double shift." - Male partner, Kpadapé

"There is a big change in my husband after we had our individual sessions. We learned so much about how to maintain harmony in our household, how he should help me with the chores and the kids. It's a really good thing but sometimes it's hard for him to help me, because he comes back from the fields and then he is tired because he gets up early to go to the field." - Female partner, Kpimé 


\section{- Reveals misperception of fertility intentions and number of children}

Home-based couples counseling brought to light dissonance between female and male fertility intentions, perceived number of children, and the power to make decisions related to FP. Interviews with men revealed that their preferred number of children is strongly associated with socioeconomic motivations. Many mentioned how they had learned about the financial benefits of spacing pregnancies during the homebased counseling and group discussion sessions. This attitude often resulted in a desire for fewer children than their spouse/partner. The majority of men voiced concerns over the costs related to raising children, noting that it was often a subject of contention with their wives/partners who desired more children in a shorter interval than men. For example, out of the 10 husbands who participated in the study, six said that they had to convince-often unsuccessfully - their female partners to use some form of contraception. Interviews with female partners confirm this finding, although the association between female preference for more children (and male preference for fewer children) and its effect on a woman's intention to use contraceptive remains unclear. Overall, our qualitative data show that women tend to want more children than men, with men possibly being more influenced in their childbearing preferences by socioeconomic factors.

"The source of our conflicts is that my wife wanted other children when, by God's Grace, she had already given me a daughter and a son. I kept mentioning to her that we had financial instability which doesn't allow us to have more than two children. Then she would talk about how young she is and that she wanted more and I kept telling her, 'look if you want more, go have kids with another man.' But then, she kept talking about it and the result is that now, we have four. And finally, she now agrees to take contraception. But until then, I won't have sexual intercourse because I don't want any more children." - Male partner, Kpimé

"Well, we haven't discussed the number of kids because I know my husband wants two but I envision having three." - Female partner, Kpimé

"The decisions on FP are made together. I even told him that if we have the number (of children) we want, that I will get my tubes tied and he agrees with this, except that they do not want FP for men, and even less a vasectomy." - Female partner, Kpadapé

"What interested me was the spacing of pregnancies given the financial situation." - Male partner, Kpimé

Interviews also indicate that five couples expressed a discrepancy when reporting their actual number of children, with the husband naming a different number than his wife. In two out of five couples, the wife stated that the couple had more children than her husband. This discrepancy may be explained by one member of the couple having children from a previous relationship. 


\section{- Reveals differentials in decision-making power and access to resources}

Narratives with women indicate that going to the health center for FP and child-related health services largely remains a woman's affair, although three out of twelve couples reported that, after the couple communication activities, husbands accompanied their wives to health centers specifically to acquire FP. Additionally, four out of twelve couples reported that they underwent a joint decision-making process regarding FP choice and initiation, both before and after the intervention.

While results show an increase in couple communication related to FP and gender roles within the home, the effect of couple counseling on woman's decision-making power related to FP remains unclear. Interviews with women reveal mixed results, with women largely having the final say in the choice of the contraceptive method, while men hold the financial power over whether their wives/partners access SRH and FP services. For example, several men explained that their wives/partners had made their own decisions regarding FP choice and use. While these statements were confirmed by the spouses/partners, they also suggest that the men still provide the money for women to access FP services.

Although results show that men are generally supportive in terms of providing their spouses with the financial resources needed to access FP services, they do highlight an important finding: women may have the power to make FP decisions and to choose her preferred method, her ability to obtain it depends on whether she has access to the monetary resources required for FP which are still largely controlled/ facilitated by men within the household.

Beyond these gender dynamics within the couple, findings also show the complexity of couple decisionmaking determinants about FP, which are not just the result of personal choice, such as a man wanting to have control over whether to give money to his spouse or not, but it is also influenced by economic pressures, religious ideologies, local supply-and-demand reality, use and side effects of modern contraception, power in couple relations and the nature of a couple's relationship - all of which affects FP decision making and use. Indeed, economic pressure came up several times in the interviews as one significant barrier to accessing contraception. For example, one female respondent revealed that she discontinued use of Depo-Provera because it was too expensive, opting instead for a contraceptive implant, which she received free of charge.

Numerous respondents also mentioned side effects, another important factor in FP decision-making, when discussing why they discontinued a number of contraception methods. Gender dynamics also appeared to play a role, as one female respondent mentioned that she planned to get a bilateral tubal ligation (BTL) when she was finished having children, partly because her husband refused to use FP or get a vasectomy. 
Additionally, power was an important element, as one woman discussed how her husband had previously acquired a mistress when she expressed fear of FP and refused to have sexual relations with him, but, after the intervention, she initiated contraception and their relationship improved.

"It's my wife who went to the health center. She talked about a pill she is taking for three months, but I didn't really understand the explanation, just that she can't be pregnant for three months. She is the boss, so I just gave her the money and went with it." - Male Partner, Kpimé

"It's me who told my husband I wanted to take Depo Provera and when I spoke with him, he didn't refuse. He gave me the money and I just went to get it." - Female Partner, Kpimé

"I used Depo-Provera, but lately it had become more expensive. Before they gave you an injection for 250f, now it has become 500f. So, when I learned during the sessions that there is a 3-year method and we were told after that that there would be an FP service campaign, and when the time came, I came to get the method (Implanon). It was done for free and that was good." - Female partner, Kpimé

"Currently she removed the 5-year one to get a 3-month injection. It was together that we decided to change the 5 -year one, because the duration is a bit long and the effects are also the basis for the change." - Male partner, Kpimé

\section{- Facilitates contraceptive decision-making and agreement}

Results suggest that home-based counseling and group discussions provided couples with more information about available FP methods, and helped them to better inform their previously-made decision to initiate contraception. During interviews, several couples explained that they had already planned to initiate contraception prior to participating, or were already using it, but the counseling helped the couples to better understand their options when they wanted to begin using FP, or to use an alternative method due to side effects. However, four couples expressed discrepancies regarding when they planned to use and acquire contraception, vis-à-vis the counseling. For example, one man noted that he and his wife had not yet made any decisions regarding family planning, but his wife said separately that they had been using FP prior to the counseling intervention and had opted to switch methods due to the counseling they received. Another man claimed that he and his wife did not know about FP before the counseling intervention. However, his wife said separately that she had wanted to initiate FP and, although her husband refused to let her use it, she did opt to use it anyway. The wife explained that this decision caused strife in their marriage, but that the intervention helped her husband accept her use of FP.

There were also several respondents who reported going to the health center after attending home-based counseling sessions, but it is unclear whether these participants did this as a result of the intervention or had already planned to go prior to their participation. For nine of the twelve couples interviewed, at least 
two members expressed that the couple had been using FP before they participated in the couple communication activities. Additionally, four couples out of twelve expressed that they had been interested in initiating contraception previous to their participation in the couple communication activities. It appears that the intervention provided couples with important knowledge on which method to choose and moved them towards consonance regarding FP.

"About FP I have to say that I had already started using a method before those training sessions. But after the sessions I now decided to use Implanon instead of Jadelle or DepoProvera that I used in the past." - Female partner, Kpadapé

“We have not yet made a decision, we are aware of planning and spacing pregnancies." - Male partner, Kpadapé

"We were told about FP, and how to live well in your relationship. I liked the topic of FP because before, there were rumors about methods, I was very scared. When my husband even asked me to do this, I refused, because we were told it caused a lot of diseases, but now I have enough information about FP." - Female partner, Kpadapé

"I wanted my wife to use traditional methods to avoid pregnancy but after the session we said that we have to go to the hospital to get products for this." - Male partner, Kpimé

\section{$\underline{\text { Unintended positive consequences }}$}

Results also point to some unintended positive consequences resulting from MCSP's couple communication intervention which could be used as additional channels to promote male engagement in FP uptake.

\section{- Offers older children an avenue for increased awareness of gender equity and FP and SRH information}

Findings suggest some positive effects on children as a possible unintended consequence resulting from home-based couple counseling. Women, in particular, noted that home-based counseling provides an opportunity for older children to access SRH information and FP services, and to be exposed to positive messages related to equitable gender roles within the home. A few men also said that couple counseling gives their children a good example of how to support one another in a relationship to achieve family harmony. One man wanted his children to attend group discussions so that they could learn from the various perspectives presented. Another man mentioned that, although his children did not attend sessions, he and his wife impart the information they learned from the counseling intervention to their children. 
"It's always the topic of FP that I really liked. I even asked the question last time to know if, for example, I have a daughter who goes to school but takes risks by going to boys' houses, I can bring her so we can give her FP and I was told that yes, it's not just for married women, but for everyone. That we can give her FP and teach her that this does not give her the green light to go around because there are diseases. Me, this news made me really happy, because there was a case like this and everyone spoke ill of the woman that she is teaching her daughter to stray; people really criticized her a lot. But, for me, it is a good thing. It is something new that I learned." Female partner, Kpadapé

"I wish for my children to follow the group discussions, because the group discussions will allow them to acquire more knowledge by learning from others and sharing their point of view." - Male partner, Kpadapé

"It is nice when the CHW comes in our home because then my children can listen to what she tells us. And they can learn from it. Already, my daughter told me last time that she wants to have a husband who will help her out around the house." Female partner, Kpimé

"When the CHW comes in our home and we talk about some of our problems but also about what makes us happy, my children listen. And I think it gives them a good example of how we try to resolve issues so that we can be happier in the family. For example, she [CHW] talks about how it's important that I help my wife around the house. And I think it's a good thing for my kids to hear this." - Male partner, Kpadapé

\section{- Desire to be exposed to the intervention sooner}

Several respondents expressed the wish that they had been exposed to these couple communication approaches sooner, explaining that it would have made an even greater positive impact on their lives. Participants specifically mentioned that the counseling led to important realizations and changed previously "ignorant" attitudes and behaviors. One respondent also noted that, had the intervention started earlier, the participants would have been "model" or ideal couples.

"These sessions have made us realize a lot of things and that's really good. If we had started sooner, our lives would be different." - Female partner, Kpimé

"Yes, I would've liked to have had these sessions sooner because these sessions have improved our relationship, it has helped us to have now a better understanding between us." - Male partner, Kpadapé

"Yes, if we had had these trainings sooner, our relationship would be different, we wouldn't have evolved with certain shortcomings.” - Female partner, Kpadapé 
"We would like to have these sessions sooner to not regret today the errors that were made." - Male partner, Kpadapé

\section{- Demand for couple's counseling in the community through other channels such as religious leaders and services}

In addition, participants indicated that there is community demand for couple counseling activities because couples feel that they learn a lot about their health and well-being through the sessions. Many suggested that CHWs and providers work with religious leaders to build their capacity to communicate similar information to communities, including by working with religious leaders and church members to promote couples counseling activities. It is important to note that this finding came out strongly during Phase 1 but not during Phase 2.

\section{Gender differences around couple communication approaches' preferences and perceived needs}

Although couple counseling was a positive experience overall for all participants, with perceived improvements in couple communication related to FP and improved shared responsibilities within the home, important gender differences with respect to women's and men's preferences and perceived needs for counseling were noted and may have important implications for programmatic action.

Table 2: Gender preferences around couple communication approaches

Home-Based Couple Counseling

Women's perceptions:

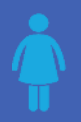

- Prefer individual home-based counseling over joint home-based counseling.

- Raises men's awareness of inequitable gender norms and roles.

- Increases knowledge on the need to space births and care for personal health.

- Improves communication with children.

\section{Men 's perceptions:}

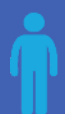

- $\quad$ Prefer joint home-based counseling over individual home-based counseling.

- Raises men's awareness of inequitable gender norms and roles and their implications for harmony within the home.

- Increases knowledge on the need to space births and methods of contraception for women and men.

- Offers a space to discuss sexual difficulties in couples. 


\begin{tabular}{|c|c|}
\hline & $\begin{array}{l}\text { - Understand the need to engage with and } \\
\text { take care of children. }\end{array}$ \\
\hline \multicolumn{2}{|c|}{ Group Discussions and Causeries Éducatives } \\
\hline Women's perceptions: & Men's perceptions: \\
\hline $\begin{array}{l}\text { - Allow to see one's situation through } \\
\text { others' similar experiences. } \\
\text { - Enjoy meeting with other women and } \\
\text { realize that others have similar issues. }\end{array}$ & $\begin{array}{l}\text { - Encourage discussions around FP and birth } \\
\text { spacing. } \\
\text { - Strengthen group knowledge of and } \\
\text { engagement in FP use. } \\
\text { - Improves understanding of the need to } \\
\text { share household chores with their female } \\
\text { partners. }\end{array}$ \\
\hline
\end{tabular}

\section{- Home-based counseling afforded an opportunity to privately discuss sensitive issues}

Overall, couples (women and men) praised home-based couple counseling for its potential to provide a space to handle conflict through concerted dialogue, as well as for the sense of comfort and trust counseling provides in terms of discussing specific couples-related issues. For eight of the twelve couples interviewed, four members expressed a preference for home counseling over group discussions. They explained that they preferred home counseling over group discussions because it allowed the couple to focus on topics that directly affected them, instead of discussing broader subjects. Women, in particular, felt home-based couple counseling raised men's awareness of inequitable gender norms and roles, particularly those related to household activities, going to the health center, and raising children. Women were more likely to appreciate couple counseling for its sessions on how to space births and take care of their health, while men tended to be more interested than women in obtaining information on specific methods, their side effects, and how to maintain harmony in the home.

In particular, two women reported that they preferred individual home-based counseling over group discussions, explaining that it allowed them to speak more freely about contentious issues with their spouse, or private subjects relating to women. Two other women also mentioned that, while they did not personally feel uncomfortable attending counseling with their husbands, they thought that spouses should be counseled separately at first, to give women who do feel uncomfortable a space to speak. This is in line with CHWs' experiences who reported that there are times when an individual counseling session is preferred to avoid conflicts that may arise during a joint counseling session. On the other hand, men expressed an overwhelming preference for participating in sessions as a couple, rather than individually. There were two main reasons for this: (i) when participating together, both spouses could gain the same understanding of the discussion or be less likely to forget what was discussed later; (ii) participating 
together allowed spouses to keep each other accountable and encourage upkeep of the practices and behaviors that were discussed. Only one man expressed an interest in participating in counseling sessions alone, without his spouse.

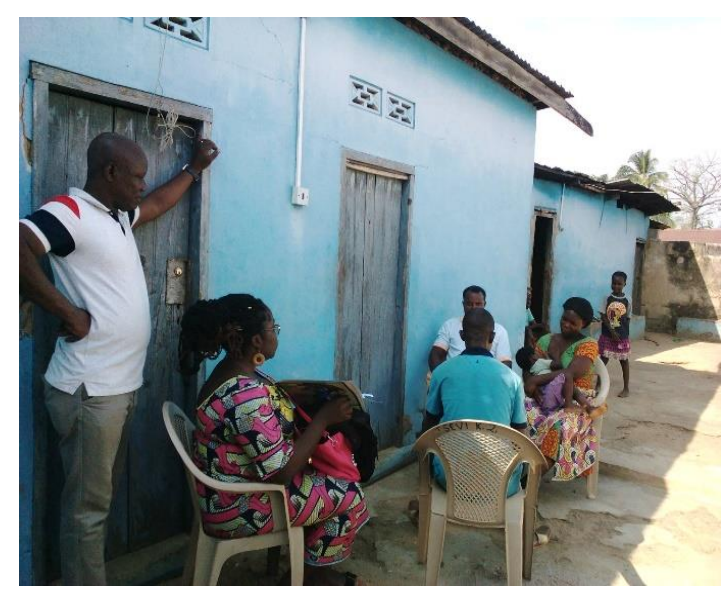

Home-based (joint) couple counseling. Photo Credit: Jhpiego, Lomé

Several men, as well as CHWs, noted that an individual session with a woman and a male CHW may trigger feelings of jealousy from the husband/partner who may also perceive the session as a way to set her against him.

"The session, we do it together and I prefer it that way because that way, each listens to what the other has to say and I don't have to think that maybe the CHW is trying to plot something against me because I am a man." - Male partner, Kpimé.

"I would prefer the couples counseling at home, because with the couple we can delve deeper on things, the trainers can give advice that corresponds with our reality. In a group, each person takes what interests them and can also copy bad behaviors or messages from others and ignore what is most important." - Female partner, Kpimé

"I participate in the sessions with my husband. And I think it is better this way, because if each one follows separately, it will be harder to put into practice the advice that is given" - Female partner, Kpadapé

"We attend the session together, because if there is a child we will manage this together, and if there is suffering we will face this together as well." - Male partner, Kpimé

Another preference for home-based counseling noted by several men was being able to raise questions about sexual difficulties in couples. However, one man in Kpadapé noted that he preferred to attend group sessions without his wife, so that he could discuss "certain [shameful] topics" without her.

\section{- Group-based discussions afforded a space for community-wide discussion on sensitive issues}

Examination of group discussions also highlights some important gender-related variance. Men expressed certain advantages to group discussions, but for different reasons than those they mentioned regarding home-based counseling. They noted that group discussions are a great avenue to see that others have similar problems, and, as such, to see one's situation more clearly and realistically. One man also noted that group discussions are a good way to gain advice about these problems. However, one man did explain 
that the group discussions made him uncomfortable at first, because they discussed taboo topics, but he felt more comfortable with them over time. Group discussions, especially causeries éducatives were perceived by men as a way to encourage discussion among the group, particularly with respect to FP and the need to space births and to provide support to one another through questions and reflection.

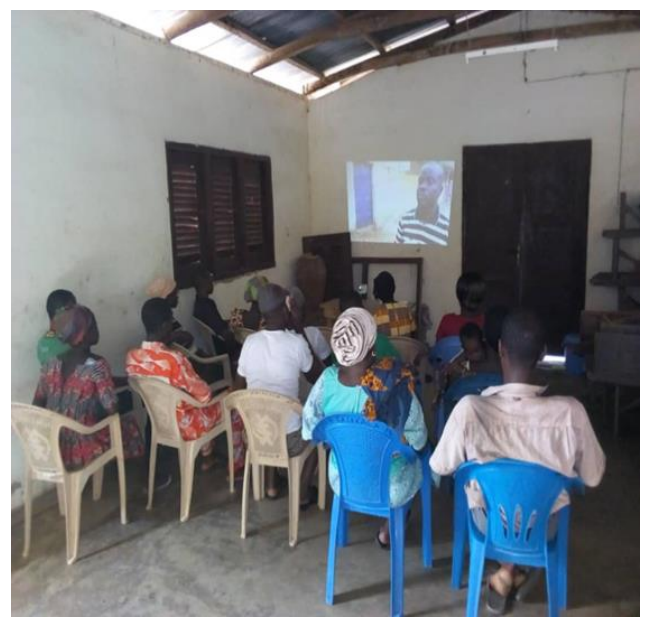

Group-based couple discussion, using videos.

Photo Credit: Jhpiego, Kpadapé
For example, during group discussions, others may ask questions that they themselves would not have thought of or feel comfortable raising. On the other hand, several women said that at times, when others share information, they feel some pressure to divulge personal issues, making them feel uncomfortable. One woman said that she felt there were certain issues that could not be brought up during group discussions. However, other women felt that the group discussions were a good place to talk about couple communication and family planning. Both men and women expressed appreciation for the video projections during groupbased discussions, noting that other people in their community could benefit from them. One negative aspect of the group discussions mentioned by two women were that other couples sometimes disrupted the discussions, getting them off track, by

asking numerous questions. One man also mentioned the infrequency of the sessions as a negative aspect, explaining that, while they were held monthly at the beginning, the sessions started to be offered quarterly, which he said made it difficult to retain the information.

"Yes, we decided together to follow these group sessions because we listen to examples from other couples allowing us to learn from them and pull advice." - Male partner, Kpadapé

"The group counseling sessions are more educational thanks to the video projections that don't require much explanation. In these projections, we see our own realities and this pushes us to change our behavior for the good of the relationship." - Female partner, Kpadapé

“The subject I liked the best was about the couples' communication, how to speak with your children with love... But it is ideal for the couple to be there together, that way each one ensures the couple puts the advice into practice. Otherwise, I am more comfortable when I participate with my husband. Based on the images we were shown, each one spoke to say what they understood without reservation and everything was dynamic." - Female partner, Kpimé

"I felt a little uncomfortable because, in our African societies, these are taboo topics that you should not expose, but with time I understood the importance." - Male partner, Kpadapé 
These findings suggest that gender is an important consideration when implementing the couple communication activities. Most women in both Kpimé and Kpadapé prefer individual couple counseling because it tends to focus more on personal issues and on raising awareness of gender equitable roles, while men, particularly in Kpadapé, see group discussions (particularly group-based discussions) as an effective way to strengthen their knowledge of and engagement in FP use.

\section{- Men's attendance was a challenge due to mismatch with men's work schedule}

Results indicate that men's attendance can be problematic because the timing of couple counseling sessions and group discussions does not always match with men's work schedules. Couples and CHWs noted the difficulty getting the couples together at the same time because, more often than not, men are out working in the fields or overseas at the time the counseling sessions are scheduled. However, CHWs are encouraged to conduct sessions on Sundays and other times, at which men may be available.

"For me, the most difficult is to find husbands with their wives because most of the men don't stay at home during the day. They work in the fields and they come back late."-Female CHW, Kpadapé

“...for the couple sessions, we do them separately because I am not available [due to work]." - Male partner, Kpadapé

"Sometimes the time of the sessions coincides with our income generating activities, which is not good about the organization of the sessions." - Male partner, Kpimé

Relatedly, ensuring attendance requires a lot of preparation time for $\mathrm{CHWs}$ who often have to make several phone calls in advance at their own cost to encourage attendance.

"Often, it's a challenge because we try to get the couple together but then I'm available only when the husband is in the field. So, if I come and give the info to the wife, the husband is going to wonder why I came to see his wife. He can think that I am trying to convince her to take some pill." - Male CHW, Kpadapé

"What is difficult is that when I come, often men are not around, which is a waste of my time, because then I can't talk to the wife alone. So you travel all the way, make plans, but then the husband isn't around." - Male CHW, Kpadapé 


\section{$\underline{\text { CHW' and Providers' Perspectives }}$}

Providers and $\mathrm{CHWs}$ described their experiences working with couples during the counseling intervention, providing details about specific preferences they observed, including: i) perceptions of CHWs regarding couples' gender preferences for couple communication approaches; ii) perceptions on couple preferences for discussion themes; (iii) perceptions on couple preferences for couple communication approaches and;

(iv) CHW perspectives on couple communication approaches. They also explained any perceived changes that they noticed in couples who had been exposed to the intervention. Implementers, providers, and $\mathrm{CHWs}$ also suggested several intervention changes that would improve $\mathrm{CHWs}$ ' performance in home-based counseling as well as for group discussions.

\section{- Perceptions on couple preferences for discussion themes}

CHWs described some gendered differences regarding topic preference, with men preferring to discuss intimacy in the marriage, and women favoring to raise the issue of male engagement in the home and birth spacing. However, other CHWs did not specifically mention topic preference by gender but did describe some commonly preferred themes among couples. These topics include conflict resolution, couple decision-making, FP and birth spacing, and child care. CHWs also noted two topics that couples often avoid or reject are vasectomies and FP among youth.

"I noticed that men will sometimes ask me things about intimacy, like why their wives won't be intimate with them. Women never really bring that up." - Female CHW, Kpadapé

"The themes they seem to talk the most about is about how to discuss to one another in a couple, how you resolve conflict. They also like the topic on how you should care for your children and talk to them." - Female CHW, Kpadapé

"The topic that people do not appreciate is when you tell them about FP among youth. It always creates a lot of discussion and they say, 'no, a mother cannot bring her daughter to do FP.' So one time, I brought a midwife so she could talk more to them about it and the reason why it's not a bad thing." - Female CHW, Kpadapé

"The topics that seem to be most appreciated by wives tend to be FP and birth spacing. For husbands, it tends to be the harmony in the couple and how to make their family happy." - Male CHW, Kpimé 


\section{- Perceptions on couple preferences for the two couple communication approaches}

Providers and $\mathrm{CHW}$ s explained that couples preferred to have counseling sessions at their houses, rather than in a public space, because it is more convenient and they feel more comfortable discussing sensitive topics. However, one provider mentioned that couples and groups were more likely to participate in the counseling if they were approached through public awareness campaigns. Several couples noted during their interviews that they chose to participate in the intervention because they knew and trusted the CHWs providing counseling.

Several CHWs also noted some gendered preferences for the two couple communication approaches, suggesting that women's attendance tends to be greater than that of men for group-based discussions, because men are usually in the field or on their way back from the field. However, they also mentioned that both men and women are often engaged during home-based counseling. One CHW also explained that the topic of conversation may vary depending on the gender of the participants(s), describing how she is more likely to discuss family life and household chores if she is counseling men.

"We take advantage of every opportunity to talk with men who are in groups. If you want to have them come, they won't come. So during visits, if we see a bunch of men together talking, we take advantage of it and we talk about our intervention. In fact, it's mostly with men that we do it, because women don't often go under a tree to talk. It does happen sometimes that we will go to church and then when we leave church, we will see a bunch of couples together, so we take advantage of it and we talk. That's when we have something close to 'group discussion."' - Female CHW, Kpimé

"When we go to the couple's house, they tend to be more comfortable and much more open than when they are in a group discussion because they don't want to talk about personal stuff. So in my experience, they prefer homebased counseling." - Male provider, Kpimé

"What I can say is that home-based visits have really facilitated our work. Otherwise, people don't like it if you tell them to go meet such and such group so we can do awareness. It takes away their time and sometimes it's far for them. So when you come to their house, they must prefer it and then, they're more open." - Female CHW, Kpadapé

\section{- Perceived changes in couples after intervention exposure}

Providers and $\mathrm{CHW}$ s observed some changes in couples within the community after being exposed to the intervention. These changes mostly relate to FP and couple communication. Several providers and CHWs said that they noticed more husbands accompanying their wives to the health centers, husbands that are more engaged in their children's health, and an overall increase in demand for FP among couples. The 
providers and CHWs were also told that the exposed couples fight less and that some men try to help their wives with household chores. The providers detailed how they assess changes after intervention exposure, including tracking the frequency of couples who visit the health center, and whether they were referred by CHWs.

"Men accompany their wives to the health center more, whether it be for consultation, FP, and even how to deliver. [For] changes in the community, people say that there is a reduction in conflicts. There isn't any resistance about the themes that we address but there is one topic that, last time, wasn't received well by couples and it was FP for adolescents who are 15 years old. Parents said that it's a free ticket for sexual promiscuity. About engaging men in household tasks, it's coming slowly. Change doesn't come abruptly, just very slowly." - Female provider, Kpimé

“We get messages that are really nice about husbands who say that they've resolved their issues with their wives or vice versa. Some women say their husbands now take care of their children. Even myself, I definitely see more men accompanying their wives to a health center, I also see couples being more receptive to FP methods." Female CHW, Kpimé

"We started with awareness. We went to churches several times to do awareness. And each time a husband accompanies his wife or a wife accompanies her husband to the health center, we gave them as an example, and we make sure they are registered at the desk as, 'accompanied by his wife,' or 'accompanied by her husband,' or 'accompanied by their two parents.' This is what we tell them we expect from them, so that there is harmony in their family." - Female provider, Kpimé

"The changes I see that are the most significant in my opinion and as a result of counseling are that men share domestic chores at home with their wives; that you see fewer conflicts or disputes within the couple; and fewer pregnancies within the couple or at least, more spaced." - Male provider, Kpimé

\section{- $\quad \mathrm{CHW}$ perspectives on couple counseling}

CHWs seemed to prefer counseling couples together, rather than during one-on-one sessions. Two CHWs explained that counseling couples together during home-based counseling often avoided conflicts and prevented the "ping-ponging" of information, where couples say contradictory things separately, which stalls any progress during the sessions. However, three CHWs also mentioned that some couples have difficulty opening up about certain topics when they are together, particularly the wife. In these instances, some CHWs opted to meet with couples on their own first, to discuss these topics, and then come back together afterward. Another $\mathrm{CHW}$ also said that he used this method if couples began to fight during a joint session. CHWs also stated that couples seemed to enjoy being counseled together, rather than separately, particularly male participants. However, two CHWs noted that bringing couples together for joint sessions 
can sometimes be difficult because of the husband's work schedule, which can prevent overall progress in the counseling sessions.

"The way we do our visits is first to see the couple together. And sometimes, when you see that they start fighting or that there is some misunderstanding, then we stop and take them separately. Then, we can come together." Female CHW, Kpadapé

"It happens sometimes that the couple are together and the wife can't open up and say what is wrong and when I realize it, it is when I meet them on their own, and they can tell me what's wrong." - Female CHW, Kpimé

"I prefer doing the couple counseling together to avoid conflicts." - Male CHW, Kpimé

In addition, CHWs highlighted key persistent challenges with FP program implementation (see Annex 2 for details).

\section{Limitations}

This assessment has a few limitations worth noting. First, given the small size of our study, the results are not generalizable to all of the couples who have taken part in the intervention. However, the findings remain valid, as they are representative of individuals who participated in the intervention in this small, rural, homogenous community. Second, due to the limited power and sample size of the study, we are unable to test the pilot scales for the self-efficacy measures. However, based on their application in this study, these measures may be used/adapted/tested further and could be helpful to estimate the effect of couple counseling intervention activities on self-efficacy among program participants. Third, our assessment of the intervention would have benefited from more detailed information about the activities (e.g. number of sessions delivered; how many sessions each couple was supposed to participate in; specific topics covered in the sessions; etc.). This information was not readily available at the time of analysis. Subsequent examination of these details would allow for a deeper analysis related to the intervention impact on gender equitable norms and FP intentions and behavior. For instance, while the separate interventions were implemented in the two sites (home based vs. group based), some CHWs took the initiative to also offer community-based sensitization activities around FP and gender roles in their sites. This initiative by the CHWs may have an additional unintended positive consequence of the intervention and may require further investigation. 


\section{Key Takeaways and Learnings from MCSP's Couple Communication Intervention}

The findings of this assessment have important implications for MCSP's way forward to expand the couple communication interventions, as well as other implementing partners involved in male engagement in Togo.

- Family planning is an important element of women's and men's well-being, but results indicate that there is dissonance between female and male FP intentions, with nuanced and varying degrees of decision-making power, mainly stemming from men's economic power.

- They also point to some unintended positive consequences resulting from the MCSP's couple counseling intervention, which could suggest additional channels for engaging men in FP uptake and expanding intervention services in the future.

- Results also indicate some gendered perspectives on the advantages of one couple communication approach over another. It is important to consider different gendered needs and perspectives when planning and implementing communication programs, for depending on the purpose and content, these communication programs might be received differently by women and men.

Below are some of the key takeaways from the results that a couple counseling intervention should consider in order to improve couple communication through effective male engagement.

I. Consider intervening early on in a couple's relationship to identify its differing needs and facilitate communication and decision-making to achieve joint fertility preferences.

Findings point to a discrepancy between women's and men's desires and needs for FP, suggesting that couple counseling should intervene early on in a couple's relationship to help the couple achieve its joint fertility preferences. In addition, it is important for counselors to acknowledge that there is not one ideal contraceptive method - "to each couple its contraception"14 - that is, counselors ought to be trained to help couples make an informed and voluntary FP choice by considering a number of factors and preferences, including, among others, the nature of a couples' relationship, couple's motivation for FP, economic constraints and religious beliefs.

2. Raise awareness and train more CHWs in gender awareness for the scaling up of successful FP interventions to recognize and address power dynamics within the couple and its structural parameters during home-based and group-based couple discussions.

Matching couple counseling sessions to women and men's preferences and needs is essential for meeting the needs of both members of the couple with respect to FP use. The discrepancy between FP desires and 
preferences between women and men were reflected in participants' narratives. This finding suggests that the counseling training should incorporate a gender component into the scale-up of FP interventions, with appropriate counseling tools within regular CHW training to help counselors identify and address gendered power imbalances and fertility desires while also recognizing each-women's and men's-experience of perceived disempowerment in relation to FP preferences.

Results related to group-based couple discussions indicate that there is a need to pay attention to group composition. In some cultures, women do not actively voice their opinions in group settings when men are present. In a given setting, women may be more comfortable speaking with women; therefore, having women in a group discussion can provide in-roads to more effectively communicate with women about couples' issues. Therefore, if needed and as appropriate, holding separate meetings may be beneficial.

In some settings, men will dominate a conversation, which means that the issues that matter most to them may also dominate the counseling session. It may be useful to identify the issues that women in the community care most about, and, if necessary, bring these issues up for discussion at the mixed-sex group discussions or couple counseling sessions. It is therefore important for counselors to have gender awareness training in order to better facilitate group-based couple counseling sessions.

\section{Take measures to match counseling sessions with men's work schedule.}

Findings suggest that successful couple counseling programs should take into account the workload and schedule of both partners while also being sensitive to $\mathrm{CHWs}^{\prime}$ availability and work load. Because CHWs are based in the community, it may be easier for them than facility-based providers to find opportunities to reach couples within their own daily schedules and those of men and women.

\section{Capitalize on CHWs adaptation and improvisation to enhance couple communication approaches}

Although a number of the findings presented in this report are commonly observed in interventions involving $\mathrm{CHWs}$, there are some learnings worth noting which are specific to the intervention activities implemented by MCSP. First, the data from the assessment revealed that couples could be reached individually, as couples, or in group settings - thus, making it a flexible intervention approach. As a result, these approaches could potentially be integrated into a number of future FP and SRH interventions. The results also revealed that $\mathrm{CHWs}$ relied on improvisation and creativity at certain points during the intervention to ensure that the counseling sessions were more useful to the couples participating. This finding, once again, points to the inherent flexibility of the intervention, as well as the potential for $\mathrm{CHW}$ to develop a deeper connection with the 
participants by adapting the intervention to their circumstances. Finally, the data suggested that the couple communication approaches not only improved the well-being and relationships of the couples who participated, but also the CHWs and providers who delivered the services. For example, multiple CHWs and providers reported integrating the lessons of the counseling sessions into their personal lives and diffusing the information among friends and peers. This suggests that this intervention is not only a transformative force for the participants, but one that also may leave a lasting impact on the implementers.

\section{Some key learnings from MCSP's couple} communication intervention:

- Flexibility

- Improvisation and creativity

- Transformative through personal growth and development 


\section{Annex I: Likert Scales Results}

A selection of couples completed in-depth interviews with trained research assistants. One interview was done early in the intervention (Phase 1: November 2018), while the second took place seven months later in the intervention stage (Phase 2: May/June 2019). During the interviews, respondents were asked to complete two scales to estimate perceived self-efficacy to discuss FP with their partner (eight items) and contraception (five items). Each scale sought to assess how couples feel about their agency, choice and power related to FP and contraception. Note that the family planning scale considers multiple domains around fertility intentions and decisions. These domains include collective/joint action; decision influence; and leadership. The contraception scale assesses similar domains on decision-making and contraceptive use. Both scales asked the respondent to rate their confidence to take a particular action or achieve a particular outcome on a scale ranging from 5, or "very certain" to 1 or not "not at all certain." The table below summarizes the scales. For details on the items for each scale, please refer to Annex 3 and Annex 4.

Table A1. Summary of perceived self-efficacy scales.

\begin{tabular}{|l|l|l|l|l|}
\hline Scale & Items & Range & Scoring & Example question \\
\hline $\begin{array}{l}\text { Self-efficacy to } \\
\text { discuss family } \\
\text { planning }\end{array}$ & 8 & $\mathrm{I}-40$ & $\begin{array}{l}\text { Likert scale I-5, where } \\
\text { I is "not at all certain" } \\
\text { and 5 is "very certain" }\end{array}$ & $\begin{array}{l}\text { How certain are you that you } \\
\text { can discuss the number of } \\
\text { children you want and when you } \\
\text { want to have them? }\end{array}$ \\
\hline $\begin{array}{l}\text { Self-efficacy to } \\
\text { discuss } \\
\text { contraception }\end{array}$ & 5 & $\mathrm{I}-25$ & $\begin{array}{l}\text { Likert scale I-5, where } \\
\text { I is "not at all certain" } \\
\text { and 5 is "very certain" }\end{array}$ & $\begin{array}{l}\text { How certain are you that you } \\
\text { would have influence on the } \\
\text { decision to use contraception? }\end{array}$ \\
\hline
\end{tabular}

Statistical analyses were conducted using R 3.6.0. Analyses and included scale construction and exploratory data analysis. Phase was dichotomized based on the timing of the interview. Likert responses were treated as ordinal, non-interval data. Regression analyses were not conducted given the small sample size.

There were 46 interviews with completed scales (22 in Phase 1, 24 in Phase 2). Of the 12 couples included, one couple was replaced in Phase 2, and two couples had a missing member during Phase 1 data collection. In the 46 interviews, there were 13 women and 13 men.

\section{$\underline{\text { Results for couples }}$}

Overall, when looking at the mean self-efficacy scores by timing, we did not see a large difference. After the counseling, there was also no observable difference between Kpadapé and Kpimé. Further investigation is warranted due to design and small sample of the current study. For instance, additional work is needed to test out the questions related to each scale to determine to which items couples had difficulty responding and how each member of the couple handled their responses. There are associated language and translation challenges when conducting research in international setting which may pose an additional layer of methodological issues. The guides, including the Likert scales were first developed in English, then 
translated into French and finally into Ewe, the local language. As a result, some of the subtleties we were trying to assess with the domains may have been lost.

Table A2. Family planning self-efficacy scales by subgroup.

\begin{tabular}{|r|r|r|r|r|}
\hline & \multicolumn{2}{|c|}{ Phase I } & \multicolumn{2}{c|}{ Phase 2 } \\
\hline & $\mathrm{n}$ & Mean score & $\mathrm{n}$ & Mean score \\
\hline Men & 10 & 36.5 & 12 & 31.4 \\
\hline Women & 12 & 29.8 & 12 & 33.9 \\
\hline Kpadapé & 10 & 33.8 & 12 & 33.7 \\
\hline Kpimé & 12 & 28.7 & 12 & 31.7 \\
\hline
\end{tabular}

Nevertheless, some interesting results emerge when we look at self-efficacy by sex of the respondents, these results are presented below.

- Perceived self-efficacy in family planning

On a scale of 7-35, the average score on this scale was 32.1, indicating high self-efficacy to discuss FP with partner. We saw a slight decrease by phase among men, and an increase for women, but are unable to assess if these are statistically significant shifts. Across all questions, the majority of respondents said they had influence and could share their opinion with their partner. For the questions regarding having "the last word" on family planning decision-making, about one-third of respondents indicated that they were not certain they would have the last word in these discussions, with slightly more men indicating they were uncertain.

Table A3 shows the breakdown by question for the family planning scale. Given the similarities between Phase 1 and Phase 2, the table is restricted to Phase 2.

Table A3. Responses to family planning self-efficacy table.

\begin{tabular}{|c|c|c|c|}
\hline & $\begin{array}{r}\text { Women } \\
(\mathrm{N}=12) \\
\mathrm{n}(\%)\end{array}$ & $\begin{array}{r}\text { Men } \\
(\mathrm{N}=\mathrm{I} 2) \\
\mathrm{n}(\%)\end{array}$ & $\begin{array}{r}\text { Overall } \\
(\mathrm{N}=24) \\
\mathrm{n}(\%)\end{array}$ \\
\hline \multicolumn{4}{|c|}{$\begin{array}{l}\text { Are you certain that you can discuss the number of children you want and } \\
\text { when to have them with your partner? }\end{array}$} \\
\hline Completely uncertain & $\mathrm{I}(8.3)$ & I (8.3) & $2(8.3)$ \\
\hline Uncertain & $0(0.0)$ & $0(0.0)$ & $0(0.0)$ \\
\hline Neither certain nor uncertain & $\mathrm{I}(8.3)$ & $0(0.0)$ & $\mathrm{I}(4.2)$ \\
\hline Somewhat certain & $4(33.3)$ & $2(16.7)$ & $6(25.0)$ \\
\hline Completely certain & $6(50.0)$ & $9(75.0)$ & $15(62.5)$ \\
\hline \multicolumn{4}{|c|}{$\begin{array}{l}\text { Are you certain that you can share your opinion with your partner regarding } \\
\text { methods to prevent or delay pregnancy? }\end{array}$} \\
\hline Completely uncertain & $0(0.0)$ & $0(0.0)$ & $0(0.0)$ \\
\hline Uncertain & $0(0.0)$ & $0(0.0)$ & $0(0.0)$ \\
\hline Neither certain nor uncertain & $0(0.0)$ & $0(0.0)$ & $0(0.0)$ \\
\hline
\end{tabular}




\begin{tabular}{|c|c|c|c|}
\hline Somewhat certain & $4(33.3)$ & $2(16.7)$ & $6(25.0)$ \\
\hline Completely certain & $8(66.7)$ & $10(83.3)$ & $18(62.5)$ \\
\hline \multicolumn{4}{|c|}{$\begin{array}{l}\text { Are you certain that your opinion will be taken into account if you discuss } \\
\text { questions about family planning? }\end{array}$} \\
\hline Completely uncertain & $\mathrm{I}(8.3)$ & $0(0.0)$ & $\mathrm{I}(4.2)$ \\
\hline Uncertain & $\mathrm{I}(8.3)$ & $0(0.0)$ & $\mathrm{I}(4.2)$ \\
\hline Neither certain nor uncertain & I (8.3) & $2(16.7)$ & $3(12.5)$ \\
\hline Somewhat certain & $3(25.0)$ & $2(16.7)$ & $5(20.8)$ \\
\hline Completely certain & $6(50.0)$ & $8(66.7)$ & $14(58.3)$ \\
\hline \multicolumn{4}{|c|}{$\begin{array}{l}\text { Are you certain that you would have the last word on the decision to use } \\
\text { family planning? }\end{array}$} \\
\hline Completely uncertain & $I(8.3)$ & $4(33.3)$ & $5(20.8)$ \\
\hline Uncertain & I (8.3) & $0(0.0)$ & I (4.2) \\
\hline Neither certain nor uncertain & $0(0.0)$ & $\mathrm{I}(8.3)$ & I (4.2) \\
\hline Somewhat certain & $2(16.7)$ & $\mathrm{I}(8.3)$ & $3(12.5)$ \\
\hline Completely certain & $8(66.7)$ & $6(50.0)$ & $14(58.3)$ \\
\hline \multicolumn{4}{|c|}{$\begin{array}{l}\text { Are you certain that you would have the last word on how and which } \\
\text { method to use to access family planning services? }\end{array}$} \\
\hline Completely uncertain & I (8.3) & $4(16.7)$ & $4(16.7)$ \\
\hline Uncertain & $\mathrm{I}(8.3)$ & $0(0.0)$ & $2(8.3)$ \\
\hline Neither certain nor uncertain & $0(0.0)$ & $\mathrm{I}(8.3)$ & $\mathrm{I}(4.2)$ \\
\hline Somewhat certain & $2(16.7)$ & $\mathrm{I}(8.3)$ & $2(8.3)$ \\
\hline Completely certain & $8(66.7)$ & $6(50.0)$ & $15(62.5)$ \\
\hline
\end{tabular}

Are you certain that you would have the last word on stopping or changing the current family planning method?

\begin{tabular}{|l|r|r|r|}
\hline Completely uncertain & $\mathrm{I}(8.3)$ & $5(4 \mathrm{I} .7)$ & $6(25.0)$ \\
\hline Uncertain & $\mathrm{I}(8.3)$ & $\mathrm{I}(8.3)$ & $2(8.3)$ \\
\hline Neither certain nor uncertain & $0(0.0)$ & $\mathrm{I}(8.3)$ & $\mathrm{I}(4.2)$ \\
\hline Somewhat certain & $2(16.7)$ & $0(0.0)$ & $2(8.3)$ \\
\hline Completely certain & $8(66.7)$ & $5(4 \mathrm{I} .7)$ & $13(54.2)$ \\
\hline
\end{tabular}

Are you certain that you have influence right now on decisions for family planning?

\begin{tabular}{|l|r|r|r|}
\hline Completely uncertain & $0(0.0)$ & $2(16.7)$ & $2(8.3)$ \\
\hline Uncertain & $2(16.7)$ & $2(16.7)$ & $4(16.7)$ \\
\hline Neither certain nor uncertain & $1(8.3)$ & $1(8.3)$ & $2(8.3)$ \\
\hline Somewhat certain & $0(0.0)$ & $2(8.3)$ & $2(8.3)$ \\
\hline Completely certain & $9(75.0)$ & $5 .(41.7)$ & $14(58.3)$ \\
\hline
\end{tabular}

Are you certain that your opinion is valued and taking into account by your partner on family planning? 


\begin{tabular}{|l|r|r|r|}
\cline { 2 - 4 } Completely uncertain & $\mathrm{I}(8.3)$ & $0(0.0)$ & $\mathrm{I}(4.2)$ \\
\hline Uncertain & $2(16.7)$ & $0(0.0)$ & $2(8.3)$ \\
\hline Neither certain nor uncertain & $0(0.0)$ & $4(33.3)$ & $4(16.7)$ \\
\hline Somewhat certain & $2(16.7)$ & $2(16.7)$ & $4(16.7)$ \\
\hline Completely certain & $7(58.3)$ & $6(50.0)$ & $13(54.2)$ \\
\hline
\end{tabular}

- Perceived self-efficacy in contraception

On a scale of $5-25$, the average score on this scale was 19.4 . We did not observe any noticeable changes in the scores by subgroup or by timing.

Table A4. Contraception self-efficacy scales by subgroup.

\begin{tabular}{|r|r|r|r|r|}
\hline & \multicolumn{2}{|c|}{ Phase I } & \multicolumn{2}{|c|}{ Phase 2 } \\
\hline & $\mathrm{n}$ & Mean score & $\mathrm{n}$ & Mean score \\
\hline Men & 10 & 21.1 & 12 & 20.2 \\
\hline Women & 12 & 17.6 & 12 & 18.9 \\
\hline Kpadapé & 10 & 19.3 & 12 & 20.2 \\
\hline Kpimé & 12 & 19.1 & 12 & 18.9 \\
\hline
\end{tabular}

Table A5 shows the breakdown by question for the contraception scale in the phase 2 interviews. Half or more of all respondents indicated that they were somewhat or completely certain of their influence on contraceptive decision-making. The questions where respondents were least certain in their influence were regarding having the last/final word regarding contraceptive choice; nearly one-third said they were uncertain.

Table A5. Responses for contraception self-efficacy scale by question.

\begin{tabular}{|l|r|r|r|}
\hline & $\begin{array}{r}\text { Women } \\
(\mathrm{N}=12) \\
\mathrm{n}(\%)\end{array}$ & $\begin{array}{r}\text { Men } \\
(\mathrm{N}=\mathrm{I}) \\
\mathrm{n}(\%)\end{array}$ & $\begin{array}{r}\text { Overall } \\
(\mathrm{N}=24) \\
\mathrm{n}(\%)\end{array}$ \\
\hline $\begin{array}{l}\text { Are you certain that you are well equipped to share your opinion } \\
\text { with your partner on methods and means of contraception? }\end{array}$ \\
\hline Completely uncertain & $0(0.0)$ & $0(0.0)$ & $0(0.0)$ \\
\hline Uncertain & $\mathrm{I}(8.3)$ & $0(0.0)$ & $\mathrm{I}(4.2)$ \\
\hline Neither certain nor uncertain & $3(25.0)$ & $0(0.0)$ & $3(12.5)$ \\
\hline Somewhat certain & $2(16.7)$ & $4(33.3)$ & $6(25.0)$ \\
\hline Completely certain & $6(50.0)$ & $8(66.7)$ & I4 (58.3) \\
\hline $\begin{array}{l}\text { During a discussion with your spouse, are you certain that your } \\
\text { partner would ask your opinion on the method of contraception } \\
\text { to use? }\end{array}$ & $3(25.0)$ & $0(0.0)$ & $3(12.5)$ \\
\hline Completely uncertain & $\mathrm{I}(8.3)$ & $0(0.0)$ & $\mathrm{I}(4.2)$ \\
\hline
\end{tabular}




\begin{tabular}{|c|c|c|c|}
\hline Neither certain nor uncertain & $\mathrm{I}(8.3)$ & $\mathrm{I}(8.3)$ & $2(8.3)$ \\
\hline Somewhat certain & $4(33.3)$ & $2(16.7)$ & $6(25.0)$ \\
\hline Completely certain & $3(25.0)$ & $9(75.0)$ & $12(50.0)$ \\
\hline \multicolumn{4}{|c|}{$\begin{array}{l}\text { Are you certain that your point of view would be taken into } \\
\text { account if you discussed which methods to use with your partner? }\end{array}$} \\
\hline Completely uncertain & $\mathrm{I}(8.3)$ & $0(0.0)$ & $\mathrm{I}(4.2)$ \\
\hline Uncertain & $2(16.7)$ & $0(0.0)$ & $2(8.3)$ \\
\hline Neither certain nor uncertain & $2(16.7)$ & I (8.3) & $3(12.5)$ \\
\hline Somewhat certain & $2(16.7)$ & $5(4 I .7)$ & $7(29.2)$ \\
\hline Completely certain & $5(4 \mid .7)$ & $6(50.0)$ & II (45.8) \\
\hline \multicolumn{4}{|c|}{$\begin{array}{l}\text { Are you certain that you would have the last word concerning the } \\
\text { methods/means used? }\end{array}$} \\
\hline Completely uncertain & $2(16.7)$ & $4(33.3)$ & $6(25.0)$ \\
\hline Uncertain & $0(0.0)$ & $2(16.7)$ & $2(8.3)$ \\
\hline Neither certain nor uncertain & $\mathrm{I}(8.3)$ & $0(0.0)$ & $\mathrm{I}(4.2)$ \\
\hline Somewhat certain & $3(25.0)$ & $0(0.0)$ & $3(12.5)$ \\
\hline Completely certain & $6(50.0)$ & $6(50.0)$ & $12(50.0)$ \\
\hline \multicolumn{4}{|c|}{$\begin{array}{l}\text { Are you certain that you would have influence on the decisions } \\
\text { made regarding methods/means used to prevent or interrupt a } \\
\text { pregnancy? }\end{array}$} \\
\hline Completely uncertain & $2(16.7)$ & $4(33.3)$ & $6(25.0)$ \\
\hline Uncertain & $0(0.0)$ & $\mathrm{I}(8.3)$ & $\mathrm{I}(4.2)$ \\
\hline Neither certain nor uncertain & I (8.3) & $\mathrm{I}(8.3)$ & $2(8.3)$ \\
\hline Somewhat certain & $2(16.7)$ & $0(0.0)$ & $2(8.3)$ \\
\hline Completely certain & $7(58.3)$ & $6(50.0)$ & $13(54.2)$ \\
\hline
\end{tabular}




\section{Results for CHWs and providers}

Overall, results indicated that in month One, the CHWs were not very confident in many of the elements, while the providers were more confident. In month Seven, however, both groups were very confident in almost all elements of counseling. Training and support appear to have contributed to improvements in perceived self-efficacy of the CHWs and providers. Results are presented below.

\section{- Perceived counseling efficacy among providers and community health workers}

In the early stages of training (Phase 1) and the late stages of training (Phase 2), six community health workers (CHWs) and two health care providers answered questions about their perceived efficacy in counseling couples on family planning and contraception. Questions were answered on a scale 1-3 (not confident, somewhat confident, very confident). There were 21 questions, with a range of possible scores 21-63. All eight respondents completed the pre- and post-tests. The table below summarizes the scores.

Table A6. Perceived counseling efficacy by provider type and phase.

\begin{tabular}{|r|r|r|}
\hline & \multicolumn{2}{|c|}{ Median score (range) } \\
\hline & Phase I & Phase 2 \\
\hline CHWs & $25.5(21-45)$ & $60.0(55-63)$ \\
\hline Providers & $42.5(37-48)$ & $61.0(59-63)$ \\
\hline
\end{tabular}

In Phase 1, providers were more confident in their ability to provide appropriate counseling than CHWs. Both groups reported improvement in Phase 2. In Phase 2, both groups had nearly the same median score.

Figure A1 shows the responses by question (see Annex 3 and 4 for individual question in French) by phase. Questions included for instance:

1. You are respectful and reactive to the needs of couples

2. You treat both members of the couple equally

3. You encourage active participation in the couple for each member

4. You promote equitable decision-making

5. You use the best communication practices for communicating information

6. You advise couples on potential side effects and address the problems related to those side effects

7. You communicate the choice of methods

8. You support the couple on the changes in methods

For details on all items asked, please refer to the scale in Annex 3. The overall shift from lighter greens to darker greens represents an increase in confidence for all questions. 


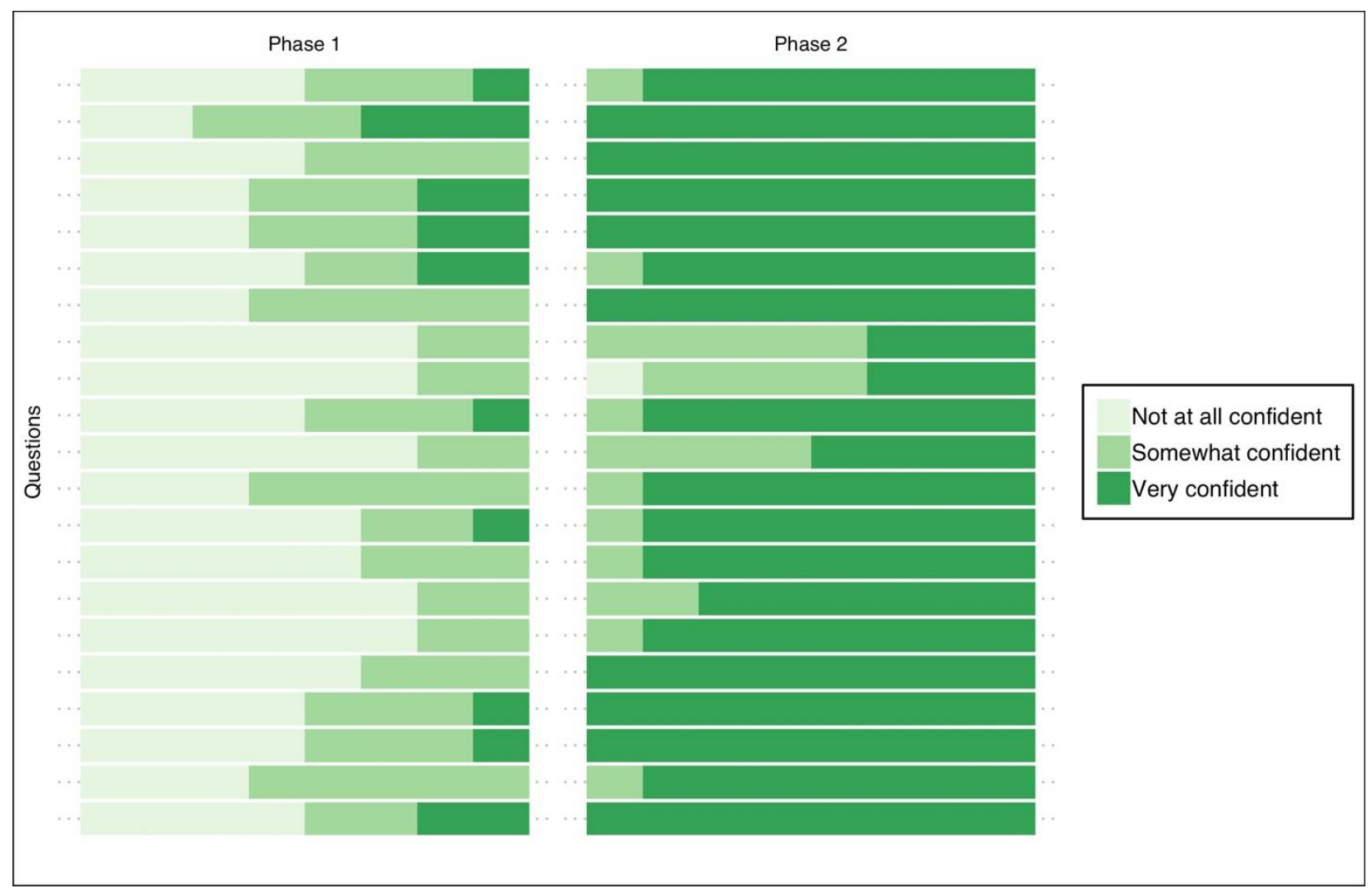

For nearly all questions, the majority of respondents said they were very confident in their abilities. For example, in Phase 1,0\% said they were very confident in their ability to preserve confidentiality; in the Phase 2, 100\% said they were very confident. In Phase 2, 100\% of respondents felt very confident in their ability to preserve confidentiality, encourage and respond to questions, and support couples in decisionmaking. 


\section{Annex 2: Resources and commodities essential for supporting family- planning interventions in the community}

The results below describe some of the challenges $\mathrm{CHWs}$ and providers reported during data collection during both phases $(1 \& 2)$. While these challenges are not particular to couple counseling/communication approaches, they reflect the persistent challenges faced by community-based FP programs.

\section{Compensation of $\mathrm{CHWs}$}

Providers and CHWs expressed an urgent need for monetary and/or non-monetary incentives to enhance their motivation and retention, as well as the effectiveness of the intervention overall. ${ }^{15}$ Many $\mathrm{CHWs}$ indicated that they do not receive a salary for their work delivering couple counseling sessions, and, as a result, they felt exploited and under-valued. Several suggested that non-monetary incentives would foster the volunteer spirit and sustain their commitment to providing couple counseling. In addition, CHWs and providers noted that constraints on their ability to travel to remote areas made it challenging to deliver home-based sessions, due to costs of transportation and lack of means to support travel. Several couples suggested that an increase in the number of $\mathrm{CHWs}$ would allow the workers to take turns and share their responsibilities, while also increasing frequency of counseling sessions and number of couples reached by the intervention. CHWs also suggested recruiting couples who have been exposed to the intervention to diffuse the information to other couples in their community in order to reach more people.

"I would say that first; we are doing this work on a voluntary basis. That in itself is hard because we don't get anything in return, except for the training itself. Then I would say please, give us something, even if it's just water, just something to motivate us because it's a hard job, to begin with. We also have a family to support." - Male CHW, Kpadapé

"I love what I am learning with this job. I also enjoy talking and getting close to my community. But it's just really hard that we don't get anything for our service. It makes it really not so motivating at times." - Female CHW, Kpadapé

"The work we do is not remunerated. Now, we are given 5000 FCFA, but when you have to go to the communities, we have to do it under the rain sometimes, and you have to cross through the bushes." - Male CHW, Kpimé

"I think that before providers can do their job well, they need to have good working conditions. We know that CHWs are not paid to come to give counseling sessions to our homes and it's a problem because then, it limits where they can go. How can we expect them to travel far if they're not even paid!” - Female partner, Kpadapé 
Similarly, one husband notes:

“The problem is not that we don't want counseling. We think it's really important but for better awareness throughout the community, the CHW needs to go to all the households and they just can't because they don't have financial support. They're not even paid to do this. So, the need is first to improve CHWs' work conditions if then you want to expand couples counseling to other communities." - Male partner, Kpimé

A technical staff working at the Ministry of Health confirms this point.

"To scale up the couple counseling activity in Togo, we have a lot to do still. For example, we need to increase resources for CHWs and providers so they can do their work well. Right now, CHWs are not paid; they do this work on a voluntary basis and this is simply not sustainable. They need to be supervised to ensure that the information they give is up-to-date. We also need a monitoring system in place to ensure effective implementation and the potential for scaling up. But for this, we need financial resources and this is where we get stuck." - DSMIPF staff, Lomé

\section{Increase resources to provide additional and ongoing technical and financial support through couples counseling refresher training and supervision of $\mathrm{CHWs}$}

CHWs and providers noted the need for additional training on the full range of contraceptive methods in both French and Ewe. Several suggested putting in place a practical and comprehensive training program that would include refresher training on the full range of available methods, their use, and side effects, in both French and Ewe. For example, some CHWs noted that during their training, most tools were in French, making the translation into Ewe challenging. They suggested supporting the training sessions with audiovisuals and flipcharts.

Relatedly, narratives with couples indicate that they are interested in receiving more information about contraceptive methods during home-based counseling sessions, because some methods are more difficult than others to use, and whether they are appropriate to use varies by one's health condition. However, they reported that $\mathrm{CHW}$ s are not always well-equipped to discuss the diverse contraceptive methods available and how they align them with the couple's specific needs, preferences, and motivations. This finding suggests needed areas of improvement at two levels: i) for both (female and male) partners, there is a need to provide comprehensive information on the use of specific contraceptive methods to support correct and continued use; and ii) for providers and CHWs, deepen their understanding of the needs, preferences, and perceptions of each couples' specific circumstances that affect FP use (i.e., religious background, health conditions, economics, a couple's power dynamic, etc.) in order to respond more effectively to their needs. Doing so will also help dispel rumors related to modern contraception and encourage continued voluntary use. 
"I think that we need to have more material and adapt the training in a way that is lighter to facilitate its use. Like have documents that are smaller and user-friendly so they can be more efficient." - Male provider, Kpimé

"We need to have more images to show because the posters they give us are practical. They rip and the quality isn't great. Also, we need more images, because people really like them.”- Male CHW, Kpimé

\section{Availability of contraceptive/FP commodities and services at the facility and community level, including those provided by $\mathrm{CHWs}$}

CHWs could play a critical role in increasing the uptake of modern contraceptives by expanding the range of methods they offer. During Phase 1, interviews with CHWs and couples indicated that unavailability of contraceptive methods in the local health center impeded contraceptive use among couples. CHWs, providers and couples noted that couples interested in some long-acting methods (e.g. implants, IUDs) or the three-monthly contraceptive injection (DMPA-IM) are required to go to the Kpalimé Prefectoral Hospital to obtain it; however, the costs associated with travel is a barrier to use. Several couples and CHWs suggested that home-based counseling would have the potential to increase contraception uptake if they were able to distribute a broader array of methods during counseling sessions. Findings indeed revealed that CHWs are trained to offer condoms, pills, and spermicide; however, although the national policy allows them to provide these methods, spermicide is not available in Togo and DMPA-IM (Depotmedroxyprogesterone acetate intramuscular administration) is available only in a handful of districts nationally, but not in Kloto.

As mentioned, this finding came out from data collection in Phase 1. By the second round of data collection however, providers and $\mathrm{CHWs}$ noted that contraceptive methods in the local health center were now available which, according to providers and CHWs makes it easier to promote contraceptive use.

"The real difficulty is that we don't have sufficient options of methods in our local health centers. If you do sensitization, then the person can go get that specific method at the Prefectoral Hospital of Kpalimé because it's not available in our local health centers. So, the person may have money for the contraception but not for traveling and all associated expenses with traveling that far. So, the problem is not that he doesn't want to use it but that it's not available. For us, we continue doing our awareness campaign but it's discouraging because what's the point of telling someone use this method but then, it's not available. We as

\section{Program course-correction:}

The preliminary results from the November 2018 data collection highlighted a lack of availability of certain FP services in the health facilities in the intervention areas, in part due to staff turnover from the start of the project. Based on these results, MCSP did a coursecorrection, training four providers from two intervention sites on long-acting reversible contraception (LARCS) during an on-site training activity in March 2019. During this training, 51 women chose an FP method, including 20 implants, $2 I$ IUDs, and 10 injectables (DMPAIM), and providers are now capacitated to offer these services to community members in their catchment areas. 
providers, we would have liked to have all these various methods available with us when we go see couples." Male CHW Kpimé

"Those I sent to the health center, I always ask them how it went afterwards. And if they're happy with the method, then it's great, but if not, then I tell them to go see the provider. The other day, I sent this woman to the health center because she wanted an implant, but when she came, they didn't have it. So, I informed the provider, and he told me he would tell me when he receives it. And he did, so the woman was able to get it." - Female CHW, Kpadapé 


\section{Annex 3: In-depth interview guides for $\mathrm{CHWs}$ and Providers}

\section{Breakthrough-RESEARCH}

Guide d'entretien individuel pour les ASC et les agents de santé prestataires

Date : Heure de Début : Heure de Fin :

Enquêteur :

Identifiant du Répondant :

Prestataire : ou ASC :

District, Canton et Village :

Sexe : Age :

Niveau de Scolarisation Atteint :

Lieu de Travail :

Position dans le Service de Santé :

Nombre d'années dans cette Position :

\section{Objectifs de l'Entretien}

- Apprendre comment les ASC et les agents de santé prestataires ont participé aux formations sur l'implication des hommes et les séances de counseling du PSMI et analyser leurs perceptions de ces activités,

- Analyser comment les expériences et comportements des ASC et des agents de santé prestataires peuvent affecter le déroulement des séances de counseling de couples et identifier comment améliorer ces séances

- Comprendre la façon dont les hommes et les femmes participants aux séances de counseling de couples étaient mis en contact avec les services de planification familiale.

\section{Introduction à l'entretien}

Utilisez le texte suivant pour introduire l'entretien au participant : 
Bonjour, je m'appelle Une fois encore, merci d'avoir pris le temps de venir me parler aujourd'hui. Comme je l'ai dit, nous travaillons avec le Projet Jhpiego / Survie Maternelle et Infantile (PSMI) pour mieux comprendre votre expérience de la participation aux séances de counseling. Nous discuterons au moins pendant une heure et demi aujourd'hui.

N'hésitez pas à partager ce que vous pensez réellement des sujets que nous aborderons aujourd'hui. Il n'y a pas de bonnes ou mauvaises réponses ou commentaires. S'il y a des questions auxquelles vous ne voulez pas répondre, tant mieux. Avez-vous d'autres questions avant que nous ne commencions?

\section{III.Questions de l'Entretien}

SECTION 1. Antécédents et rôle en tant que prestataire

J'aimerais commencer avec des informations sur ce que vous faites ici en tant qu'ASC ou prestataire de service

1. Pouvez-vous me parler un peu de vous et de votre rôle en tant qu' [ASC] ou [prestataire] ? Quels genres de choses faites-vous ? Qu'est ce qui a changé depuis la dernière fois?

2. Qu'est-ce que vous aimez dans votre travail ? Quelles sont les choses que vous n'aimez pas beaucoup dans votre travail ?

SECTION 2. Pre-Counseling : Expériences quant à la formation sur le PSMI J'aimerais commencer avec quelques questions concernant la formation que vous avez suivie avec Jhpiego / PSMI concernant l'engagement des hommes et le counseling de couples

3. Comment avez-vous commencé par mettre en œuvre et/ou soutenir les activités liées aux groupes de discussions en couples et le counseling de couples? Approfondir:

$\rightarrow$ Qu'est ce qui a changé depuis la dernière fois ?

$\rightarrow$ Aviez-vous compris ce que l'on attendait de vous après la formation?

$\rightarrow$ Qu'est-ce qui a été facile concernant le début des activités ? Quelles étaient les difficultés?

$\rightarrow$ Que disent les gens à propos du counseling de couples/implication des hommes ?

$\rightarrow$ Avez-vous ajusté certaines activités ? Si oui, pourquoi et comment avez-vous ajusté ces activités?

[SI C'EST UN-E ASC] SECTION 3a. Durant les groupes de discussions en couple et le counseling: Expériences avec les séances de counseling en couples et groupes de discussions en couples dans la communautél A présent, passons à quelques questions concernant votre travail avec les couples. 
Note pour l'enquêteur/trice : Pensez à la différence entre les hommes et les femmes ? Quels sont les thèmes les plus abordes par les femmes ? les hommes ?

4. J'aimerais que vous réfléchissiez à votre expérience et interaction avec les couples pendant les séances de counseling de couples à domicile (séparés ou en couple). En général, comment se déroulent les séances avec les couples lors des visites à domicile ?

Approfondir :

$\rightarrow$ Les couples sont-ils ensemble en général ? Préfèrent-ils avoir une séance seuls/es (avec ou sans 1'époux/se ? Pourquoi ? Approfondir (plus les maris ? les épouses ?)

$\rightarrow$ Quelles sont les éléments de discussions qui semblent être les plus discutés et appréciés par les couples? Approfondir pour les épouses et les époux

$\rightarrow$ Quelles sont les éléments de discussions qui semblent être moins discutés et appréciés ? Pourquoi ? Approfondir pour les épouses et les époux

$\rightarrow$ Et les matériels? (ex. cartes de counseling, vidéo, boite à images, etc.). Comment les avez-vous utilisés?

$\rightarrow$ Quels matériels avez-vous trouvé plus ou moins utiles ? Pourquoi cela ?

$\rightarrow$ Quelles difficultés avez-vous rencontré lors des séances ? Et comment les avezvous surmontées?

$\rightarrow$ Est-ce que c'est plus souvent avec un des conjoint.e.s ou avec le couple ensemble?

$\rightarrow$ Qui tend à engager la discussion plus que d'autres ou prend la parole plus que d'autres? les maris ? les épouses? Approfondir

5. Est-ce que vous préférez faire du counseling à domicile avec le couple ensemble ou seule-a-seule avec le mari ou la femme ? Pourquoi ça ? Très important****

6. Selon vous, en quoi le fait d'être femme ou homme ASC affecte votre manière de faire du counseling à domicile ? Approfondir***

$\rightarrow$ Est-ce que le couple est plus ouvert s'il s'agit d'une femme conseiller ou un homme conseiller? Est-ce que le fait d'être [si de sexe masculin] un ASC homme ou [si de sexe féminin] une ASC femme vous a faciliter ou pas les discussions ? Si oui, quels thèmes étaient les plus faciles ou difficiles à aborder ? Pourquoi ? Approfondir

7. J'aimerais que vous réfléchissiez à votre expérience et interaction avec les participants et/ou couples pendant les séances de groupes de discussions en couples. Comment se déroulent les groupes de discussions en général ? Sondez :

$\rightarrow$ Quelles sont les éléments de discussions qui semblent être les plus discutés et appréciés par les couples? Approfondir

$\rightarrow$ Quelles sont les éléments de discussions qui semblent être moins discutés et appréciés ? Pourquoi ? Approfondir 
$\rightarrow$ Et les matériels ? (ex. cartes de counseling, vidéo, boite à images, etc.). Comment les avez-vous utilisés ?

$\rightarrow$ Quels matériels aviez-vous trouvé plus ou moins utiles ? Pourquoi cela ?

$\rightarrow$ Quelles difficultés avez-vous rencontré lors des discussions en groupe ? Et comment les avez-vous surmontées ?

$\rightarrow$ Pensez à la différence entre les hommes et les femmes ? Quels sont les thèmes les plus abordes par les femmes ? les hommes?

$\rightarrow$ Qui tend à engager la discussion plus que d'autres ou prend la parole plus que d'autres? les maris ? les épouses ? Approfondir.

8. Qui vient le plus souvent ? Les hommes ou les femmes ? Ou viennent-ils ensemble ? Pourquoi ? Très important****

9. Selon vous, en quoi le fait d'être femme ou homme ASC affecte votre manière de faciliter les groupes de discussions ? Approfondir***

$\rightarrow$ Est-ce que le couple est plus ouvert s'il s'agit d'une femme conseiller ou un homme conseiller? Est-ce que le fait d'être [si de sexe masculin] un ASC homme ou [si de sexe féminin] une ASC femme vous a faciliter ou pas les discussions ? Si oui, quels thèmes étaient les plus faciles ou difficiles à aborder ? Pourquoi ?

\section{Approfondir}

10. Selon vous, quels types de compétences faut-il avoir pour être un bon conseiller ou facilitateur de séances de counseling avec les couples ? Approfondir $* * *$

$\rightarrow$ Par exemple, concernant la communication, la facilitation, l'écoute, etc.

$\rightarrow$ Ce sont les mêmes discussions avec le couple que les discussions que vous avez si c'est juste la femme ou l'homme?

11. Pouvez-vous me dire en quoi les thèmes et questions abordes sont différentes s'il s'agit d'une femme ou d'un mari ? (Très important***)

12. Selon vous, quels types de compétences faut-il avoir pour être un bon facilitateur de séances de groupes de discussions avec les couples ? Approfondir $* * *$

$\rightarrow$ Par exemple, concernant la communication, la facilitation, l'écoute, etc.

$\rightarrow$ Par exemple pour faire prendre la parole a tout le monde, quelles sont les meilleures stratégies? Par exemple, les femmes des fois peuvent être plus timides que les hommes? que faites-vous pour les faire parler plus ? ou est-ce que ce sont les hommes qui sont plus timides?

13. Quel soutien avez-vous eu lors de la mise en œuvre des activités ? Approfondir****

$\rightarrow$ Par votre superviseur au centre de santé ? Et/ou le personnel ? Veuillez expliquer.

$\rightarrow$ Est-ce que vous communiquez souvent avec votre superviseur au centre de santé concernant les activités de counseling ?

$\rightarrow$ De quoi discutez-vous ou avez-vous déjà discuté avec votre superviseur en lien avec les activités de counseling de couples ? 
$\rightarrow$ Pensez-vous que vous disposez des orientations, outils et ressources nécessaires pour mettre en œuvre les activités ? Veuillez expliquer.

14. Parmi les couples participants, y en a-t-ils qui sont ou ont été intéressés par l'utilisation des méthodes de PF (ex. pilules, injections, implants, etc.) ? Approfondir****

$\rightarrow$ Si oui, quelles méthodes ? Approfondir en citant les noms des méthodes***

$\rightarrow$ Les avez-vous envoyés vers un centre de santé ? Comment cela a fonctionné pour eux?

$\rightarrow$ Pouvez-vous me donner un exemple ou me raconter l'histoire d'un couple qui s'était rendu au centre de santé après la séance de counseling à domicile ou en groupe ? Que s'est-il passé ensuite ? Comment ont-ils été accueillis ?

$\rightarrow$ Comment avez-vous fait le suivi avec les couples, les femmes et/ou les hommes qui étaient allés au centre de santé pour rechercher plus d'informations sur la PF ?

15. Y a-t-il des changements positifs ou négatifs que vous avez déjà remarqués/observés dans la communauté grâce aux séances de counseling de couples à domicile et groupes de discussions en groupes? Très important et Approfondir****

$\rightarrow$ Donnez-moi deux ou trois exemples de changement que vous avez remarqué depuis que les séances de counseling et groupes de discussions ont été mises en œuvre.

$\rightarrow$ Utilisation des services de PF ? Et/ou à propos des methodes de PF ?

$\rightarrow$ Utilisation des services en général par les hommes ? Par les femmes ? Le couple ensemble?

$\rightarrow$ Est-ce que vous voyez des gens qui sont contre ces séances ?

16. Par rapport à ces changements, qu'est-ce que vous remarqué ? Que les hommes participent plus aux décisions liées à la planification familiale? Ou aux tâches ménagères ? Expliquez en quoi ces changements sont bien ou pas bien pour la communauté ?

[SI C'EST UN-E PRESTATAIRE] SECTION 3b. Après le counseling. Compétences pour superviser et faire les seances de counseling et les groupes de discussion À présent, passons aux questions liées avec votre expérience par rapport aux activités de counseling de couples.

17. Quelle était votre expérience quant à la supervision des ASC chargé de la mise en œuvre des activités de counseling de couples? Approfondir***

$\rightarrow$ Qu'est-ce qui a été plus difficile ou plus facile ?

5. Communiquez-vous fréquemment avec les ASCs ? Souvent? Pas souvent? Quels sont les obstacles de communication?

6. Lorsque vous communiquez avec les ASCs, de quoi parlez-vous ?

7. Dans quel domaine en général ont-ils besoin le plus de soutien ?

8. Pensez-vous que vous disposez des orientations, outils et ressources nécessaires pour superviser et soutenir les activités ? Pourquoi ? Approfondir*** 
18. Selon vous, quelles compétences faut-il avoir pour être un superviseur des activités de counseling de couples à domicile ou lords des groupes de discussions? Approfondir $^{* * *}$

9. Sont-elles différentes des compétences nécessaires pour superviser d'autres formes de counseling sur la PF ?

19. Selon vous, en quoi le fait d'être femme ou homme prestataire affecte votre manière de superviser les ASC? Approfondir $* * * *$

$\rightarrow$ Est-ce que l'ASC est plus ouvert s'il s'agit d'une femme conseiller ou un homme prestataire?

20. Selon vous, en quoi le fait d'être femme ou homme prestataire affecte la manière dont l'ASC fait ses séances de counseling ou facilite les groupes de discussions?

Approfondir****

$\rightarrow$ Est-ce que le fait d'être [si de sexe masculin] un ASC homme ou [si de sexe féminin] une ASC femme vous a faciliter ou pas les discussions? Si oui, quels thèmes étaient les plus faciles ou difficiles à aborder? Pourquoi ? Approfondir

21. Selon vous, quels types de compétences faut-il avoir pour être un bon facilitateur de séances de groupes de discussions avec les couples? Approfondir $* * *$

$\rightarrow$ Par exemple, concernant la communication, la facilitation, l'écoute, etc.

$\rightarrow$ Par exemple pour faire prendre la parole a tout le monde, quelles sont les meilleures stratégies ? Par exemple, les femmes des fois peuvent être plus timides que les hommes? que faites-vous pour les faire parler plus ? ou est-ce que ce sont les hommes qui sont plus timides?

22. Pouvez-vous me dire en quoi les thèmes et questions abordés sont différentes s'il s'agit d'une femme ou d'un mari ? (Très important***)

23. Selon vous, quels types de compétences faut-il avoir pour être un bon facilitateur de séances de groupes de discussions avec les couples? Approfondir $* * *$

$\rightarrow$ Par exemple, concernant la communication, la facilitation, l'écoute, etc.

$\rightarrow$ Par exemple pour faire prendre la parole a tout le monde, quelles sont les meilleures stratégies? Par exemple, les femmes des fois peuvent être plus timides que les hommes? que faites-vous pour les faire parler plus ? ou est-ce que ce sont les hommes qui sont plus timides?

24. Y a-t-il des changements positifs ou négatifs que vous avez déjà remarqués/observés dans la communauté grâce aux séances de counseling de couples à domicile et groupes de discussions en groupes? Très important et Approfondir****

$\rightarrow$ Donnez-moi deux ou trois exemples de changement que vous avez remarqué depuis que les séances de counseling et groupes de discussions ont été mises en œuvre.

$\rightarrow$ Utilisation des services de PF ? Et/ou à propos des méthodes de PF ? 
$\rightarrow$ Utilisation des services en général par les hommes ? Par les femmes ? Le couple ensemble?

$\rightarrow$ Est-ce que vous voyez des gens qui sont contre ces séances?

25. Par rapport à ces changements, qu'est-ce que vous remarqué ? Que les hommes participent plus aux décisions liées à la planification familiale ? Ou aux tâches ménagères ? Expliquez en quoi ces changements sont bien ou pas bien pour la communauté ?

26. Comment le fait d'être conseiller/facilitateur/superviseur des activités de counseling de couples a influencé votre vie ? Professionnellement et/ou personnellement ?

\section{Approfondir $* * *$}

$\rightarrow$ Votre rôle dans la communauté a-t-il changé, ou est resté le même, en raison de votre travail avec Jhpiego ? Pouvez-vous me donner un exemple ?

$\rightarrow$ Avez-vous appris quelque chose sur vos propres compétences ou aptitudes alors que vous mettiez en œuvre les activités?

$\rightarrow$ Y-a-t-il quelque chose que vous avez découvert sur vous-même ?

SECTION 4. Mesure de l'auto-efficacité*

27. Avant et après avoir reçu la formation sur le counseling de couples, nous voulons savoir sur une échelle de 1 à 3 avec 1 =pas confiant, 2=quelque peu confiant, et 3 =très confiant. Quel était votre degré de confiance concernant (Enquêteur rempli le classement d'appréciations avant et après la formation pour chaque question) :

\begin{tabular}{|c|l|l|}
\hline Sujet & $\begin{array}{l}\text { Classement du degré de } \\
\text { confiance (avant) }\end{array}$ & $\begin{array}{l}\text { Degré de confiance } \\
\text { (après avoir participé à la } \\
\text { formation au counseling } \\
\text { de couples) }\end{array}$ \\
\hline $\begin{array}{l}\text { 6.1. Vous êtes respectueux et } \\
\text { réactifs aux besoins des } \\
\text { couples, comme : }\end{array}$ & \\
\hline $\begin{array}{l}\text { 6.1.1. Vous } \\
\text { préservez l'intimité } \\
\text { et la confidentialité } \\
\text {; }\end{array}$ & & \\
\hline $\begin{array}{l}\text { 6.1.2. Vous écoutez } \\
\text { les clients et } \\
\text { répondez à leurs } \\
\text { besoins }\end{array}$ & & \\
\hline $\begin{array}{l}\text { 6.1.3. Vous utilisez } \\
\text { un ton amical et un } \\
\text { langage corporel } \\
\text { attentif. }\end{array}$ & & \\
\hline $\begin{array}{l}\text { 6.2. Vous traitez les deux } \\
\text { conjoints équitablement } \\
\text { par exemple : }\end{array}$ & & \\
\hline
\end{tabular}




\begin{tabular}{|c|c|c|}
\hline $\begin{array}{l}\text { 6.2.1. Vous veillez à ce } \\
\text { que les deux conjoints } \\
\text { aient l'opportunité } \\
\text { d'exprimer leurs points de } \\
\text { vue }\end{array}$ & & \\
\hline $\begin{array}{l}\text { 6.2.2. Vous répondez aux } \\
\text { questions des deux } \\
\text { conjoints }\end{array}$ & & \\
\hline $\begin{array}{l}\text { 6.2.3. Vous créez une } \\
\text { ambiance conviviale pour } \\
\text { les deux conjoints }\end{array}$ & & \\
\hline $\begin{array}{ll}\text { 6.2.4. Vous } & \\
\text { résolvez/atténuez } & \text { les } \\
\text { conflits de façon } \\
\text { appropriée }\end{array}$ & & \\
\hline $\begin{array}{l}\text { 6.3. Vous suscitez une } \\
\text { participation } \\
\text { active chez les } \\
\text { couples ; par } \\
\text { exemple : }\end{array}$ & & \\
\hline $\begin{array}{l}\text { 6.3.1. } \begin{array}{l}\text { Vous encouragez les } \\
\text { couples à poser des } \\
\text { questions }\end{array} \\
\end{array}$ & & \\
\hline $\begin{array}{l}\text { 6.3.2. } \\
\text { Vous vous assurez que } \\
\text { les couples ont } \\
\text { compris l'information }\end{array}$ & & \\
\hline $\begin{array}{l}\text { 6.3.3. Vous encouragez les } \\
\text { couples à raconter leur } \\
\text { histoire }\end{array}$ & & \\
\hline $\begin{array}{ll}\text { 6.3.4. } & \text { Vous recherchez les } \\
\text { informations et } \\
\text { demandez aux couples } \\
\text { les informations qu'ils } \\
\text { veulent avoir } \\
\end{array}$ & & \\
\hline $\begin{array}{l}\text { 6.4. Vous faites la } \\
\text { promotion de la } \\
\text { prise de décision } \\
\text { équitable, par } \\
\text { exemple } \\
\end{array}$ & & \\
\hline $\begin{array}{l}\text { 6.4.1. Vous conseillez les } \\
\text { couples sur leurs } \\
\text { points de vue et les } \\
\text { soutenez dans leur } \\
\text { prise de décision } \\
\end{array}$ & & \\
\hline
\end{tabular}




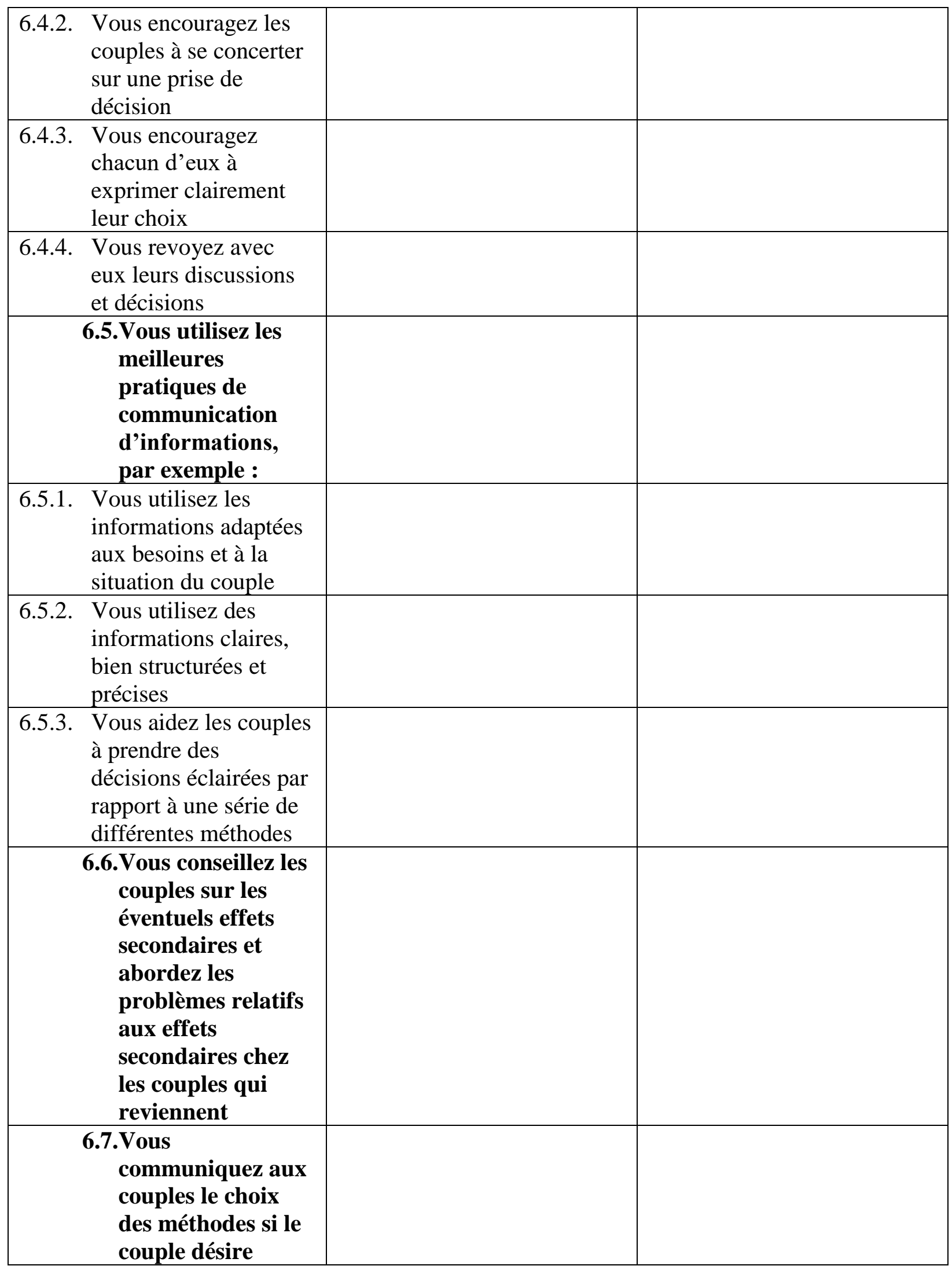




\begin{tabular}{|l|l|l|}
\hline $\begin{array}{l}\text { changer de } \\
\text { méthodes }\end{array}$ & \\
\hline $\begin{array}{l}\text { 6.8. Vous soutenez les } \\
\text { couples dans le } \\
\text { changement des } \\
\text { méthodes si le }\end{array}$ & & \\
couple désire & & \\
changer de & & \\
méthodes & & \\
\hline
\end{tabular}

28. Donnez-moi deux ou trois exemples du changement le plus important que vous avez remarqué dans votre communaute par rapport à l'intervention du counseling à domicile et des groupes de discussion? [Notez à l'endroit de l'enquêteur : Si le participant mentionne un changement, veuillez leur demander de donner 2-3 exemples] Pourquoi <sujet> a-t-il changé ? Comment a-t-il changé ? Pouvez-vous donner un exemple? Pourquoi <sujet> n'a-t-il pas changé ?

29. Aussi, pouvez-vous me dire qui vient plus aux séances de counseling à domicile ?

$\rightarrow$ Les hommes ou les femmes ou les deux ? pourquoi ?

30. Et aux groupes de discussion, ce sont plus les hommes ou les femmes ou le couple ensemble?

31. Et en général, pouvez-vous me dire si entre le counseling à domicile ou en groupe, qui tend à venir plus? les hommes ? les femmes ? c'est-à-dire, est-ce que vous remarquez que les hommes ou femmes préfèrent plus le counseling à domicile ou en groupe ? $\mathrm{Tt}$ pourquoi?

SECTION 6. Recommandations pour le counseling de couples Nous sommes presque à la fin. J'aimerais vous poser quelques questions finales concernant la façon d'améliorer ce programme.

32. Si un ami désire devenir un facilitateur/conseiller de counseling de couples, quel conseil lui donneriez-vous? 
33. Y-at-il quelque chose à changer dans la formation, le guide pour les séance à domicile ou discussions des couples en groupe, le matériel pour faciliter la mise en œuvre et/ou appuyer le counseling avec les couples et discussions en groupe ?

34. Quels autres moyens peut-on utiliser pour impliquer les couples et/ou les hommes dans les services de counseling dans vos communautés d'intervention?

\section{CLOTURE. Avez-vous d'autres questions}

Remerciez les participants pour leurs réflexions et contributions, demandez-leur s'ils ont d'autres choses à partager avant la cloture:

35. Y-a-t-il autre chose que vous souhaiteriez partager avec nous? 


\section{Annex 4: In-depth interview guides for couples}

\section{Breakthrough-RESEARCH}

Guide d'Entretien Individuel pour les hommes et les femmes participants au counseling de couples

Date : Heure de Début : Heure de Fin :

Enquêteur :

Identifiant du Répondant-e :

Identifiant du Couple :

District, Canton et Village :

Sexe : Age : Niveau de Scolarisation Atteint :

Année de Mariage :

Nombre d'Enfants :

Nombre de séances de counseling de couples à domicile suivies :

Nombre de séances de groupes de discussions en couple reçues :

\section{IV.Objectifs de l'Entretien}

- Identifier les raisons de la participation des femmes et des hommes aux séances de counseling a domicile et aux groupes de discussions en couple

- Comprendre les expériences des femmes et des hommes en ce qui concerne le counseling dans tout le continuum de soins - avant, pendant et après avoir reçu les services

- Explorer le rôle et le potentiel du counseling de couples dans la communication et la prise de décision au sein du couple concernant l'utilisation des services/méthodes de PF

\section{Introduction de l'entretien}

Utilisez le scenario suivant pour introduire l'entretien au participant : 
Bonjour, je m'appelle Une fois encore, merci d'avoir pris le temps de venir me parler aujourd'hui. Comme je l'ai dit, nous travaillons avec le Projet Jhpiego / Survie Maternelle et Infantile (PSMI) pour mieux comprendre votre expérience de la participation au counseling sur la planification familiale. Nous discuterons au moins pendant une heure et demi aujourd'hui.

N'hésitez pas à partager ce que vous pensez réellement des sujets que nous aborderons aujourd'hui. Il n'y a pas de bonnes ou mauvaises réponses ou commentaires. S'il y a des questions auxquelles vous ne souhaitez pas répondre, tant mieux. Avez-vous d'autres questions avant que nous ne commencions?

\section{Questions de l'Entretien}

SECTION 1. Antécédents et relations des participants D'abord, j'aimerais qu'on fasse un peu plus ample connaissance. Veuillez nous parler un peu de vous, qui vous êtes et d'où vous venez. Je peux commencer [enquêteur : veuillez partager quelques informations sur vous n'ayant aucun rapport avec l'utilisation de la PF]

1. Depuis quand êtes-vous marié et/ou vivez-vous avec votre partenaire ?

2. Combien d'enfants avez-vous ? Quel est l'âge du plus jeune ?

3. Pouvez-vous nous parler de vos relations avec votre époux/épouse, c'est-à-dire est-ce que vous vous entendez bien? Approfondir*** sur les choses positives et les difficultés dans leurs relations.

4. Pouvez-vous parler un peu de la manière dont vous avez participé aux séances de counseling de couples?

$\rightarrow$ Aviez-vous pris la décision ensemble avec votre conjoint(e) ou seule(e) ? Pour quelles raisons ?

$\rightarrow$ Avez-vous parlé à quelqu'un d'autre de votre décision de participer aux séances ? Par exemple un autre membre de la famille, un ainé ou un(e) ami(e) ?

$\rightarrow$ Aviez-vous déjà une méthode en tête quand vous avez participé à la séance de counseling de couples à domicile ou en groupe ou utilisez-vous déjà une méthode ?

5. Pouvez-vous parler un peu de la manière dont vous avez participé aux séances de counseling et des groupes de discussions en couple ?

$\rightarrow$ Aviez-vous pris la décision ensemble avec votre conjoint(e) ou seule(e) ? Pour quelles raisons?

$\rightarrow$ Avez-vous parlé à quelqu'un d'autre de votre décision de participer aux séances ? Par exemple un autre membre de la famille, un ainé ou un(e) ami(e) ?

$\rightarrow$ Aviez-vous déjà une méthode en tête quand vous avez participé à la séance de counseling de couples à domicile ou en groupe ou utilisez-vous déjà une méthode ? 
SECTION 2. Relations avec le(la) conjoint(e) et conversations autour de la planification familiale

Avant que nous ne discutions de quelques raisons de la participation aux séances de counseling de couples, j'aimerais en savoir plus sur la façon dont vous et votre et votre conjoint(e) discutez du nombre d'enfants à avoir et des questions liées aux méthodes de planification familiale avant votre participation au counseling de couples.

6. Pouvez-vous nous parler des conversations que vous avez déjà eu ou que vous avez avec votre conjoint sur la planification familiale?

$\rightarrow$ Comment parlez-vous avec votre conjoint du désir du nombre d'enfants ou de l'espacement des enfants, etc. ?

$\rightarrow$ Qui commence en général la conversation ? Pourquoi ?

$\rightarrow$ Étiez-vous d'accord ou en désaccord avec votre conjoint(e) ?

$\rightarrow$ Comment la discussion a-t-elle pris fin ?

$\rightarrow$ Qui d'autres a participé à la discussion?

Approfondir*** - Note à l'enquêteur : Cherchez à connaitre les opinions de chaque personne mentionnée comme participant à la discussion

SECTION 3. Au cours des séances de counseling : Expériences par rapport aux séances de counseling et groupes de discussions (Cette section est très importante***)

J'aimerais parler de vos expériences quant aux séances de counseling et groupes de discussions. On va commencer avec les séances de groupes de counseling.

7. J'aimerais connaitre votre expérience par rapport à votre participation aux séances de counseling à domicile ?

$\rightarrow$ A combien de séances avez-vous participé jusque-là ? (Très important)

$\rightarrow$ Aviez-vous un sujet qui vous intéressait plus que d'autres ? Pourquoi ?

$\rightarrow$ Avez-vous appris des choses que vous ne connaissiez pas ?

$\rightarrow$ Avez-vous participé aux séances ensemble avec votre conjoint-e ? Ou avezvous participé séparément?

$\rightarrow$ Vous vous êtes senti comment en présence de votre conjoint(e) lorsque le thème de la planification familiale a été abordé ? Et en présence d'autres couples durant les groupes de discussions en couple?

$\rightarrow$ Est-ce que d'après vous, le couple doit participer ensemble au counseling à domicile ou c'est mieux d'être seule seul(e) sans son/sa conjoint(e) ? Pourquoi ? (Très important***)

8. Pouvez-vous me dire ce que vous aimez ou avez aimé le plus avec ses séances ? En quoi vous sont-elles aidées ? qu'est-ce que ces séances ont changé dans votre manière de vivre et de vous comporter? (Très important***)

9. J'aimerais maintenant connaitre vos expériences par rapport à votre participation aux séances de groupes de discussions en couple avec votre conjoint(e). Approfondir*** $\rightarrow$ A combien de séances avez-vous participé jusque-là ? 
$\rightarrow$ Aviez-vous un sujet qui vous intéressait plus que d'autres ? Pourquoi ?

$\rightarrow$ Avez-vous appris des choses que vous ne connaissiez pas ?

$\rightarrow$ Avez-vous participé aux séances ensemble avec votre conjoint-e ? Ou avezvous participé séparément?

$\rightarrow$ Vous vous êtes senti comment en présence de votre conjoint(e) lorsque le thème de la planification familiale a été abordé ? Et en présence d'autres couples durant les groupes de discussions en couple?

$\rightarrow$ Est-ce que d'après vous, le couple doit participer ensemble aux groupes de discussions en couples ou c'est mieux de venir seule ? (Très important***)

10. Pouvez-vous me dire s'il y a des choses que vous n'aimez pas ou n'avez pas aimé avec ces séances de counseling ? (Très important***)

11. Prévoyez-vous de continuer à participer aux séances de counseling de couples à domicile ? Pourquoi ?

12. Pouvez-vous me dire ce que vous aimez ou avez aimé le plus avec ses séances de groupes de discussion ? En quoi vous sont-elles aidées ? Qu'est-ce que ces séances ont changé dans votre manière de vivre et de vous comporter ? (Très important***)

13. Pouvez-vous me dire s'il y a des choses que vous n'aimez pas ou n'avez pas aimé avec ces groupes de discussions? (Très important $* * *$ )

14. Prévoyez-vous de continuer à participer aux séances en groupe de discussion? Pourquoi?

15. Selon vous, en quoi le fait d'être femme ou homme ASC ou prestataire qui fait le counseling à domicile affecte la séance ?

$\rightarrow$ Est-ce que le/la facilitateur/trice était une femme ou un homme ?

$\rightarrow$ Est-ce que le couple est plus ouvert s'il s'agit d'une femme conseiller ou un homme conseiller? Pourquoi.

$\rightarrow$ En quoi les sujets sont différents entre le counseling à domicile et les groupes de discussions?

16. Selon vous, en quoi le fait d'être femme ou homme ASC ou prestataire qui facilite les groupes de discussions affecte la discussion? (Très important***)

$\rightarrow$ Est-ce que le/la facilitateur/trice était une femme ou un homme ?

$\rightarrow$ Est-ce que les couple sont plus ouverts s'il s'agit d'une femme conseiller ou un homme conseiller? Pourquoi.

$\rightarrow$ Est-ce que les hommes ont plus tendance à parler que les femmes ou ce sont les femmes qui parlent plus que les hommes?

$\rightarrow$ En quoi les sujets sont différents entre le counseling à domicile et les groupes de discussions?

$\rightarrow$ Qu'est ce qui est plus discuté en groupes de discussions par rapport au counseling à domicile ? Pourquoi ? 
SECTION 5. Post-Counseling: Dynamique de couples, communication et prise de décision concernant la SSR

J'aimerais parler maintenant de ce qui s'est passé avec vous et votre partenaire après votre participation aux séances de counseling. Avez-vous des questions avant que je ne continue?

17. Quels types de conversations avez-vous eu avec votre partenaire après avoir participé aux séances de counseling à domicile ?

$\rightarrow$ Qu'avez-vous appris lors des séances de counseling de couples ?

$\rightarrow$ Pouvez-vous me donner un exemple de conversation ? Que s'est-il passé après la conversation?

18. Quels types de conversations avez-vous eu avec votre partenaire après avoir participé aux séances de groupes de discussions?

$\rightarrow$ Qu'avez-vous appris lors des séances de counseling de couples ?

$\rightarrow$ Pouvez-vous me donner un exemple de conversation ? Que s'est-il passé après la conversation?

19. Comment votre partenaire et vous avez pris la décision concernant la planification du nombre et de l'espacement de naissances? Approfondir****

$\rightarrow$ Qui a souvent soulevé le sujet en premier ? De quels genres de choses parlezvous lors de la discussion sur quand/si avoir des enfants ?

20. Maintenant que vous avez participé aux séances, est-ce que vous auriez aimé avoir des séances de counseling et groupes de discussions plus tôt, dans votre couple ? Si oui ou non, Approfondir****

$\rightarrow$ Si oui, pourquoi ? en quoi ça vous aurait aidé, vous ou votre conjoint.e ?

$\rightarrow$ Si non, pourquoi ?

21. Est-ce que vous conseillerez à vos enfants de faire des séances de counseling s'ils/elles étaient en couple ? et les groupes de discussions ? pourquoi ?

22. En quoi est-ce que vos relations avec votre partenaire ont-elles changé, depuis le début de votre participation aux séances de counseling ? Approfondir:

$\rightarrow$ Par exemple, comment vous avez décidé de la planification et/ou prévention des grossesses ? Ou concernant le fait d'aller au centre de santé pour plus d'informations sur les services de PF ? Veuillez partager un exemple avec nous ?

$\rightarrow$ Y-a-t-il des aspects de votre relation que vous aimeriez changer? Par exemple, concernant la façon dont vous partagez les tâches ménagères ? Ou communiquez entre vous? 
$\rightarrow$ Par exemple, s'il arrive d'avoir des conflits avec votre conjoint.e, est ce que vous arrivez à mieux les gerer maintenant ? pouvez-vous expliquer en quoi ça vous a changé, vous et votre conjoint.e ?

SECTION 6. Post-Counseling : Choix de méthode et utilisation des services de planification familiale

Je vous remercie pour le partage d'expériences. A présent, j'aimerais parler de l'utilisation des services de santé, y compris la planification familiale, et de comment votre partenaire et vous avez pris la décision d'utiliser ou non les services.

23. Depuis que vous avez commencé les séances de counseling, vous-êtes-vous rendu dans un centre de santé dans votre zone ? Si oui, pour quels services ? Si non, pourquoi ? Sondez:

$\rightarrow$ Par exemple, concernant le counseling pré- et post-natal, les services de planification familiale ou la santé de vos enfants ?

$\rightarrow$ Etiez-vous accompagné(e) au centre de santé ? Si oui, par qui (partenaire, enfant, etc.) ?

$\rightarrow$ De quelles façons est-ce que votre participation aux séances de counseling a-telle influencé votre décision à rechercher les services de santé ?

$\rightarrow$ Quelles étaient vos expériences dans l'obtention des services de santé au centre de santé ? Qu'avez-vous apprécié ? Qu'avez-vous détesté ?

24. Depuis que vous avez commencé à participer aux séances de counseling de couples, est-ce que vous visitez plus les centres de santé ?

$\rightarrow$ Par exemple, est-ce que ça a changé vos relations avec l'agent de santé communautaire de la communauté ?

25. Après la séance de counseling de couples, vous-êtes-vous rendu quelque part pour obtenir plus d'informations sur une méthode spécifique de planification familiale ? Dites-moi un peu pourquoi vous avez ou n'avez pas obtenu une méthode. Si oui, Sondez :

$\rightarrow$ Etes-vous parti seul(e) ou avec votre partenaire ? Parlez-moi davantage de cela.

- $\quad \mathrm{Si}$ vous êtes parti seul(e) -> votre partenaire savait-t-il/elle que vous êtes parti(e) obtenir une méthode ?

$\rightarrow$ Avant cette expérience, votre partenaire et vous-êtes-vous rendus normalement au centre de santé ensemble?

$\rightarrow$ Parlez-moi un peu de votre expérience par rapport à la recherche de services de PF. Qu'avez-vous ressenti lors de votre visite ? Avez-vous reçu le conseil/service que vous désiriez? Qu'est-ce que vous aviez apprécié ou n'aviez pas apprécié dans le service/conseil reçu ?

$\rightarrow$ Comment l'agent de santé vous a accueilli ? Satisfait ? Pas satisfait ? Pourquoi? 
Vous et votre partenaire utilisez-vous actuellement une méthode de planification familiale ?

Répondre à toutes les questions en marquant la réponse à côté. ****

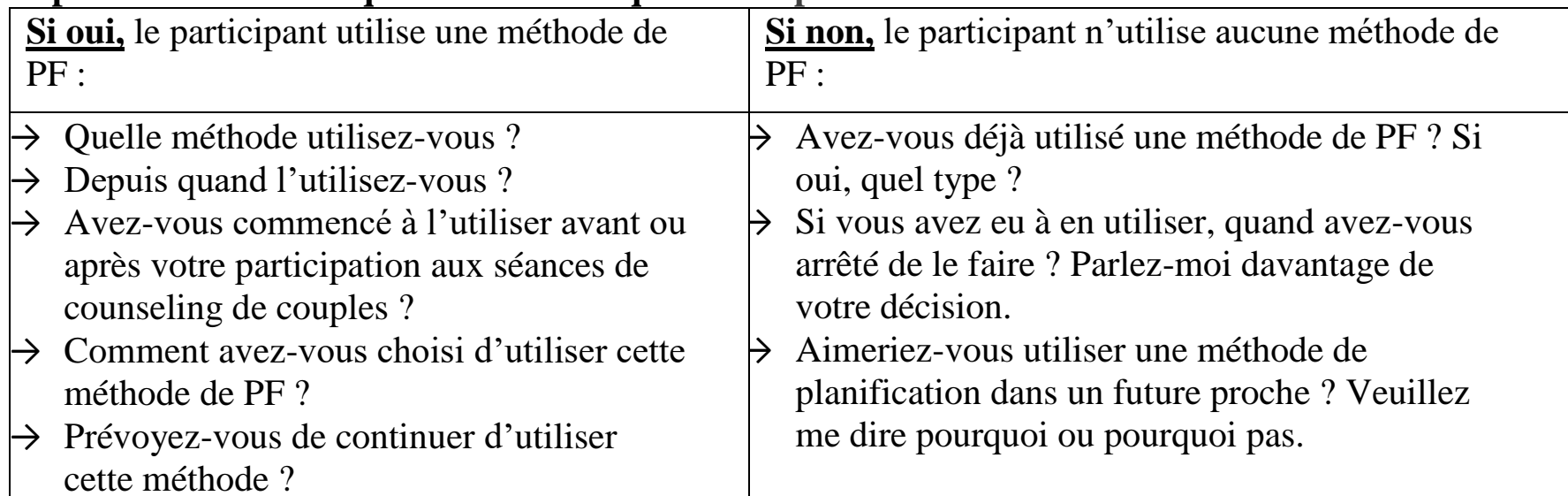

SECTION 7. Auto-efficacité sur l'autonomisation reproductive

Enquêteur : A présent, je vais vous poser quelques questions sur votre degré de confiance concernant votre capacité à discuter avec votre conjoint(e) de la planification familiale et de l'utilisation d'une méthode de PF (ou contraception). Je vais vous lire certaines déclarations. Pour chacune d'elle, je souhaiterais que vous me disiez si vous êtes tout à fait certain, certain, ni certain ni pas certain, pas certain, pas du tout certain.

\section{Options d'éléments de réponses : échelle de Likert de 5 points, où Tout à fait certain $=5$, Certain $=4$, Ni certain ni Pas certain $=3$, Pas certain $=2$, Pas du tout certain $=1$}

\section{B. Auto-efficacité à Discuter de la Planification Familiale et à l'Utiliser}

Enquêteur : A présent, je vais vous poser certaines questions sur votre degré de confiance concernant votre capacité à discuter/partager vos opinions sur l'espacement et/ou la prévention des grossesses. Même si vous ne voulez pas utiliser la PF maintenant, essayez d'imaginer un moment dans le futur où vous pourriez souhaiter utiliser la PF. Vous avez. [XX enfants]. Les choix de PF sont différents chez les hommes et les femmes selon la taille de leur famille. Ils pourraient désirer avoir plus d'enfants, attendre cette prochaine grossesse ou décider de ne plus faire d'enfants. Par conséquent, je vais à présent vous poser certaines questions relatives aux décisions de PF.

\begin{tabular}{|c|l|l|l|l|l|}
\hline $\begin{array}{l}\text { Maintenant que vous avez participé aux } \\
\text { séances de counseling et groupes de } \\
\text { discussions, }\end{array}$ & $\begin{array}{l}\text { Complètemen } \\
\text { t certain(e) }\end{array}$ & $\begin{array}{l}\text { Quelque peu } \\
\text { certain(e) }\end{array}$ & $\begin{array}{l}\text { Ni Certain(e)/ } \\
\text { Ni } \\
\text { Incertain(e) }\end{array}$ & $\begin{array}{l}\text { Quelque peu } \\
\text { incertain(e) }\end{array}$ & $\begin{array}{l}\text { Complèteme } \\
\mathrm{nt} \\
\text { incertain(e) }\end{array}$ \\
\hline $\begin{array}{c}\text { 6.1.Êtes-vous certain(e) de pouvoir } \\
\text { discuter du nombre d'enfants } \\
\text { que vous désirez (ou aurait } \\
\text { aimé) avoir et quand vous } \\
\text { souhaiteriez les avoir? } \\
\text { (action collective) }\end{array}$ & & & & \\
\hline \begin{tabular}{c} 
6. $\begin{array}{l}\text { E.tes-vous certain(e) de pouvoir } \\
\text { partager votre opinion avec }\end{array}$ \\
\hline
\end{tabular} & & & & \\
\hline
\end{tabular}




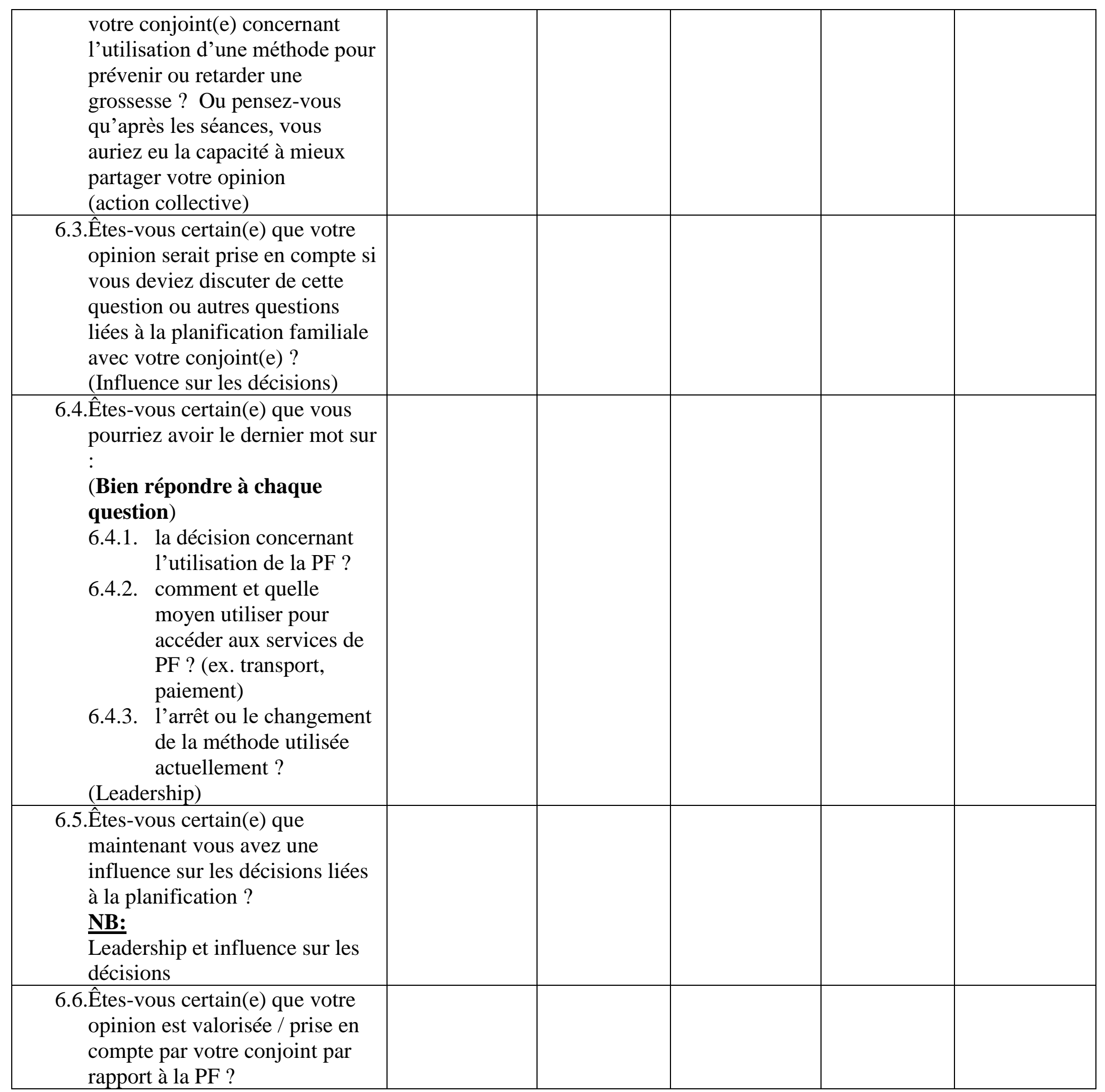


Options d'éléments de réponses : Échelle de Likert de 5 points, où Complètement $\operatorname{Certain}(\mathrm{e})=5$, Quelque peu Certain $(\mathrm{e})=4$, Ni certain/ $/ \mathrm{Ni}$ Incertain(e) $=3$, Quelque peu $\operatorname{Incertain}(e)=2$, et Complètement $\operatorname{Incertain}(e)=1$

\section{Auto-efficacité dans l'Utilisation de la Contraception}

Enquêteur : A présent, je vais vous poser des questions concernant votre niveau de confiance ou de certitude concernant votre capacité à utiliser la PF si vous le désirez. Même si vous ne voulez pas utiliser la PF maintenant, imaginez un moment dans un futur proche où vous pourriez vouloir utiliser la PF en général ou pas.

\begin{tabular}{|c|c|c|c|c|c|}
\hline $\begin{array}{l}\text { Maintenant que vous avez participé aux } \\
\text { séances de counseling et groupes de } \\
\text { discussions, }\end{array}$ & $\begin{array}{l}\text { Complète } \\
\text { ment } \\
\text { certain(e) }\end{array}$ & $\begin{array}{l}\text { Quelque } \\
\text { peu } \\
\text { certain }(\mathrm{e})\end{array}$ & $\begin{array}{l}\mathrm{Ni} \\
\mathrm{Certain}(\mathrm{e}) / \\
\mathrm{Ni} \\
\text { Incertain(e) }\end{array}$ & $\begin{array}{l}\text { Quelque } \\
\text { peu } \\
\text { incertain(e) }\end{array}$ & $\begin{array}{l}\text { Complèteme } \\
\text { nt } \\
\text { incertain(e) }\end{array}$ \\
\hline $\begin{array}{l}\text { 6.1.Êtes-vous certain(e) que vous êtes } \\
\text { en mesure de mieux partager votre } \\
\text { opinion avec votre conjoint(e) } \\
\text { concernant les méthodes/moyens } \\
\text { que vous pourriez utiliser si vous le } \\
\text { deviez (soit parce que vous voulez } \\
\text { retarder les grossesses ou parce que } \\
\text { vous ne voulez plus avoir d'enfants) } \\
\text { ? }\end{array}$ & & & & & \\
\hline $\begin{array}{l}\text { 6.2.Lors d'une discussion avec votre } \\
\text { conjoint(e), êtes-vous certain(e) que } \\
\text { votre conjoint(e) vous demanderait } \\
\text { votre opinion concernant la méthode } \\
\text { de PF à utiliser? }\end{array}$ & & & & & \\
\hline $\begin{array}{l}\text { 6.3.Êtes-vous certain(e) que votre point } \\
\text { de vue serait pris en compte si vous } \\
\text { deviez discuter de quelles } \\
\text { méthodes/moyens utilisés avec votre } \\
\text { conjoint(e)? }\end{array}$ & & & & & \\
\hline $\begin{array}{l}\text { 6.4.Êtes-vous certain(e) que vous auriez } \\
\text { le dernier mot concernant quelles } \\
\text { méthodes/moyens utilisés et agiriez } \\
\text { en ce sens? }\end{array}$ & & & & & \\
\hline $\begin{array}{l}\text { 6.5.Êtes-vous certain(e) que vous avez } \\
\text { une influence sur les décisions liées } \\
\text { aux méthodes/moyens à utiliser pour } \\
\text { prévenir ou interrompre une } \\
\text { grossesse? }\end{array}$ & & & & & \\
\hline
\end{tabular}




\section{Options d'éléments de réponses : Échelle de Likert de 5 points, où Complètement $\operatorname{Certain}(e)=5$, Quelque peu $\operatorname{Certain}(e)=4$, $\mathrm{Ni}$ certain/ $\mathrm{Ni} \operatorname{Incertain}(\mathrm{e})=3$, Quelque peu $\operatorname{Incertain}(e)=2$, et Complètement $\operatorname{Incertain}(e)=1$}

Note à l'intention de l'enquêteur:

En posant des questions sur l'auto-efficacité, il est important de sonder les réponses. Les exemples de ce qu'il faut rechercher.

\begin{tabular}{|l|l|}
\hline Type d'Enquête Cognitive & Exemple \\
\hline Compréhension/interprétation & $\begin{array}{l}\text { Que signifie les expressions "opinion partagée", "opinion sera prise en } \\
\text { compte, "avoir le dernier mot", "avoir une influence", pour vous? }\end{array}$ \\
\hline Paraphrase & $\begin{array}{l}\text { [S'il/elle affirme n'avoir pas compris les questions] : Pouvez-vous répéter la } \\
\text { question que j'ai posée en utilisant vos propres mots ? } \\
\text { Comment, selon vous, devrions-nous formuler les questions ? }\end{array}$ \\
\hline Jugement du degré de confiance & $\begin{array}{l}\text { Étiez-vous à l'aise à répondre à cette question ? } \\
\text { Pensez-vous qu'il s'agit d'une question appropriée à poser ? }\end{array}$ \\
\hline Rappel & $\begin{array}{l}\text { J'aimerais en savoir un peu plus sur comment vous êtes parvenu à cette } \\
\text { réponse que vous m'avez donnée. Dites-moi, pendant que vous écoutiez la } \\
\text { question et réfléchissiez à comment y répondre, à quoi pensez-vous ? Qu'est- } \\
\text { ce qui, selon vous, a suscité cette réponse de votre part? }\end{array}$ \\
\hline Spécifique & $\begin{array}{l}\text { [S'il/elle affirme que le/la conjoint(e) prend la décision finale] : Pourquoi } \\
\text { avez-vous dit que votre conjoint(e) prenait la décision finale? } \\
\text { [S'il/elle hésite à répondre à la question] : Pourquoi avez-vous hésité à } \\
\text { répondre à la question? }\end{array}$ \\
\hline Général & $\begin{array}{l}\text { La question était-elle facile ou difficile à répondre ? } \\
\text { Aviez-vous compris les choix de réponses ? } \\
\text { Les choix de réponses étaient-ils faciles à suivre ? } \\
\text { Aviez-vous souhaité qu'il y ait d'autres choix de réponses, si oui, lesquels ? }\end{array}$ \\
\hline
\end{tabular}

26. Quel a été le changement le plus important que vous avez remarqué après avoir participé aux séances de counseling et groupes de discussions par rapport aux questions que nous venons d'aborder? Donnez deux à trois choses qui ont le plus change dans votre vie grâce à ces séances et groupes de discussions.

27. [Notez à l'endroit de l'enquêteur] : Si le participant mentionne un changement, veuillez leur demander de donner 2-3 exemples] Pourquoi <sujet> a-t-il changé ? Comment a-t-il changé ? Pouvez-vous donner un exemple ? Pourquoi < sujet> n'at-il pas changé ? 
SECTION 8. Recommandations pour le counseling de couples et groupe de discussion Nous sommes presque à la fin. J'aimerais vous poser quelques questions finales concernant comment améliorer ce programme.

28. Quels sont les autres moyens par lesquels nous pouvons impliquer les couples et/ou les hommes dans la PF et autres services de santé ?

29. Comment ces services peuvent-ils être améliorés pour mieux répondre à vos besoins ?

$\rightarrow$ Pour les séances de counseling à domicile ?

$\rightarrow$ Pour les groupes de discussion?

CLOTURE. Autres questions

Remerciez les participants pour leurs réflexions et contributions. Demandez-leur s'ils ont d'autres choses à partager avant la clôture :

30. Y-a-t-il autre chose que vous aimeriez partager avec nous aujourd'hui ? 
${ }^{1}$ T B Koffi, K Weidert, E O Bitasse, M A Mensah, J Emina, S Mensah, A Bongiovanni, N Pratab. 2018. Engaging Men in Family Planning: Perspectives From Married Men in Lomé, Togo, Global Health: Science and Practice, http://bixby.berkeley.edu/wp-content/uploads/2018/07/GHSP-D-17-00471.full_.pdf

${ }^{2}$ Family Planning 2020. https://www.familyplanning2020.org/togo, accessed on April 02, 2019.

${ }^{3}$ Hawkes, S and Buse, K. Gender and global health: evidence, policy, and inconvenient truths. 2013. Lancet.

${ }^{4}$ Institute for Reproductive Health, Georgetown University. 2013. From Family Planning to Fatherhood: Analysis of Recent Male Involvement Initiatives and Scale-Up Potential.

${ }^{5}$ World Health Organization. 2007. Engaging men and boys in changing gender-based inequity in health: Evidence from programme interventions. Geneva.

${ }^{6}$ Institute for Reproductive Health, Georgetown University. 2017. Couples Counseling in Reproductive Health: A Review of the Literature. FACT Project. Washington, D.C.: Institute for Reproductive Health, Georgetown University.

${ }^{7}$ The focus of the activities in Kpimé was for CHWs to do home visits for couples counseling while the focus in Kpadapé was for CHWs and providers to run the videos and group-based discussions. In both areas, however, the $\mathrm{CHWs}$ also did causeries (or group sensitization) and home visits with a focus on the male engagement and couples communication components that was slightly different. It is important to note, however, that CHWs in Kpimé also took initiatives to deliver group-based discussions based on demands by couples in the community. As a result, it made it difficult, during data collection, to distinguish whether each couple member referred to group-based discussions or causeries. Because of this limitation, we decided to refer to "group discussions" throughout the report to refer to both group-based discussions and causeries.

${ }^{8}$ Community health workers also include relais communautaires (community support networks) who are trained by providers and community health workers to do community awareness and deliver counseling sessions in the community.

${ }^{9}$ A service provider differs from a community health worker (CHWs) in that she or he is recruited by the Ministry of Health. A service provider is trained as a healthcare professional and she/he receives a monthly salary. She or he can be a nurse, midwife or a doctor. A CHW is chosen by her or his community to provide health-related services at the community level. She or he does not receive a salary as her/his work is done on a voluntary basis. She or he is typically supervised by a provider who trains her or him on how to assist the community with basic health services.

10 The questions assessing self-efficacy for CHWs and providers were adapted from "Designing an SBCC Intervention for CHW Behavior Change" (I-Kit, August, 2016):

http://sbccimplementationkits.org/provider-behavior-change/wp-content/uploads/sites/10/2016/08/CommunityHealth-Workers-SBCC-Intervention-Design.pdf

11 The items in these pilot scales were developed and adapted from the following sources: 
- USAID. 2018. A Conceptual Framework for Reproductive Empowerment. Empowering Individuals and couples to improve their health. Background Paper. International Center for Research on Women (ICRW) and MEASURE Evaluation.

https://www.icrw.org/wp-content/uploads/2018/10/Reproductive-Empowerment-Background-Paper 100318FINAL.pdf

- World Health Organization. 2005. Decision-Making Tool for Family-Planning Clients and Providers. A Resource for High- Quality Counseling. https://www.who.int/reproductivehealth/publications/family planning/9241593229index/en/

- $\quad$ Designing an SBCC Intervention for CHW Behavior Change. 2016. (I-Kit, August): http://sbccimplementationkits.org/provider-behavior-change/wp-

content/uploads/sites/10/2016/08/Community-Health-Workers-SBCC-Intervention-Design.pdf

Note that for the items included in the Couples' pilot scales, our objective was to map the items to the reproductive empowerment conceptual framework developed by USAID-ICRW-MEASURE Evaluation (in the source indicated above), which include: Agency: SRH decision-making, leadership and collective action; Choice: ability to make and influence decisions related to their reproductive lives; Power: To influence or be influenced by social, economic or emotional (or physical) force.

${ }^{12}$ Daoudou I, Edem Koffi D, Arnold B and J. Agbodjavou. 2017. Évaluation Formative Rapide sur l'Engagement des Hommes dans la Planification Familiale et l'Extension des Services pour la Vasectomie sans Bistouri au Togo : Rapport Final. USAID and MCSP.

https://www.mcsprogram.org/resource/evaluation-formative-rapide-sur-lengagement-des-hommes-dans-laplanification-familiale-et-lextension-des-services-pour-la-vasectomie-sans-bistouri-au-togo-rapport-finale/

${ }^{13}$ The quotes that are presented include quotes from couples (husbands and wives or who are leaving in union).

${ }^{14}$ Mwembo-Tambwe A, Kayamba P, Donnen P, Mukalenge F, Humblet P, Dramaix M, Buekens P. 2012. Accouchées avec statut sérologique VIH inconnu à Lubumbashi, RD Congo: proposition et déterminants. The Pan African Medical Journal, vol 12; $25 p$.

${ }^{15}$ It is important to note that the Government of Togo is currently working with donors and partners to provide compensation for community health workers nationally. $\mathrm{CHWs}$ in the intervention zone currently receive 5,000f/month but Relais Communautaires, who are supposed to receive 3,000f/month have yet to receive compensation. 